NBER WORKING PAPER SERIES

\title{
HOW HOUSEHOLD PORTFOLIOS EVOLVE AFTER RETIREMENT: THE EFFECT OF AGING AND HEALTH SHOCKS
}

\author{
Courtney Coile \\ Kevin Milligan \\ Working Paper 12391 \\ http://www.nber.org/papers/w12391
NATIONAL BUREAU OF ECONOMIC RESEARCH
1050 Massachusetts Avenue
Cambridge, MA 02138
July 2006

The research reported herein was supported (in part) by the Center for Retirement Research at Boston College pursuant to a grant from the U.S. Social Security Administration funded as part of the Retirement Research Consortium. The opinions and conclusions are solely those of the authors and should not be construed as representing the opinions or policy of the Social Security Administration or any agency of the Federal Government, or the Center for Retirement Research at Boston College. The authors acknowledge the support of the Social Sciences and Humanities Research Council of Canada (grant \# 410-2006-0928). Coile acknowledges funding from Wellesley College. We thank Pierre Brochu for research assistance. This paper is a substantial revision of a working paper circulated with the title, "How Portfolios Evolve after Retirement: The Effect of Health Shocks." The views expressed herein are those of the author(s) and do not necessarily reflect the views of the National Bureau of Economic Research.

(C2006 by Courtney Coile and Kevin Milligan. All rights reserved. Short sections of text, not to exceed two paragraphs, may be quoted without explicit permission provided that full credit, including (C) notice, is given to the source. 
How Household Portfolios Evolve After Retirement: The Effect of Aging and Health Shocks Courtney Coile and Kevin Milligan

NBER Working Paper No. 12391

July 2006

JEL No. G11, J14

\begin{abstract}
$\underline{\text { ABSTRACT }}$
In this paper, we study how the portfolios of elderly U.S. households evolve after retirement, using data from the Health and Retirement Study (HRS). In particular, we investigate the influence of aging and health shocks on a household's ownership of various assets and on the dollar value and share of total assets held in each asset class. We find that households decrease their ownership of most asset classes as they age, with the strongest evidence for principal residences and vehicles, while increasing the share of assets held in bank accounts and CDs. Consistent with prior studies, we find that the death of a spouse is a strong predictor of selling the principal residence. However, we find that widowhood also leads households to sell vehicles, businesses, and real estate and to put money into bank accounts and CDs, and further that other health shocks have very similar impacts. Finally, we explore why health shocks affect asset holdings and find that the effect of a shock is greatly magnified when households have physical or mental impairments. This suggests that factors other than standard risk and return considerations may weigh heavily in many older households' portfolio decisions.
\end{abstract}

Courtney C. Coile

Department of Economics

Wellesley College

106 Central Street

Wellesley, MA 02481

and NBER

ccoile@wellesley.edu

Kevin S. Milligan

Department of Economics

University of British Columbia

\#997-1873 East Mall

Vancouver, BC

CANADA V6T 1Z1

and NBER

kevin.milligan@ubc.ca 


\section{INTRODUCTION}

The typical older household in the U.S. has considerable financial resources. In 2004, median net worth (excluding Social Security and defined benefit pension wealth) was $\$ 190,100$ for households with heads ages 65 to 74 and $\$ 163,100$ for households with heads ages 75 and above (Bucks et. al., 2006). The combined net worth of these older households was $\$ 14.5$ trillion, or nearly one-third of total U.S. household net worth. ${ }^{1}$

These assets are critical for the financial security of older households, as they may be used to finance routine consumption during retirement and to protect the household against financial risks in old age, such as those posed by a severe illness or the death of a spouse. Management of household portfolios may become even more critical to elderly well-being in the near future, due to an ongoing shift in private pensions towards defined contribution plans and the possible partial privatization of Social Security, changes which can put more responsibility on the household to manage financial assets during retirement. Moreover, because these assets represent a sizeable share of total U.S. household net worth, the spend-down patterns of older households may also have important implications for asset markets, particularly as the large baby boom cohorts enter retirement.

Despite the importance of these assets for older households' financial security and for asset markets, relatively little is known about how the portfolios of older households evolve during retirement. Several studies look at household portfolio allocation by age (Poterba and Samwick, 2001; Ameriks and Zeldes, 2002) but do not focus on the elderly. The literature on the elderly generally centers on housing equity (Venti and Wise, 1989, 1990, 2002) but does not look at other assets. A few studies explore the effect of health on elderly portfolios, but are

\footnotetext{
${ }^{1}$ This figure was calculated by the authors using the 2004 Survey of Consumer Finances.
} 
limited to looking at the effect of health on portfolio allocation in a cross-section (Rosen and $\mathrm{Wu}, 2004)$ or how changes in health affect total assets (Feinstein and Ho, 2001; Wu, 2003).

We build on the existing literature in several ways. First, we document how asset holdings evolve during old age, looking comprehensively at holdings in numerous asset classes. Second, we examine whether changes in asset holdings during old age are related to health shocks such as the death of a spouse or an event like a stroke or new cancer diagnosis. Third, we explore why health shocks affect asset holdings by examining whether physical, mental, and financial capacity influence households' responses to shocks.

The data for our analysis is the first six waves of the Health and Retirement Study (HRS), which allows us to follow older U.S. households for up to ten years, 1992-2002. In our examination of asset holdings, we look not only at the decision to hold a particular type of asset but also the dollar value and share of the household's portfolio invested in that asset class. This allows us to study both the extensive and the intensive margins of response. In our analysis, assets are grouped into five asset classes: principal residence; vehicles; financial assets including IRAs, stocks, and bonds; bank accounts and CDs; and business and other real estate.

In examining how portfolios evolve with age, we attempt to distinguish the true effect of aging from other effects. We begin simply by looking at how household portfolios vary with age in a cross-section, where age effects, cohort effects, and the effects of survivorship bias may be mingled. We then take advantage of the panel nature of the HRS to explore how the assets of the same households vary over time and to estimate models with cohort and household fixed effects. In our analysis of the effect of health shocks, we look at the effect of shocks first in a static context that compares households before and after a shock and then in a dynamic analysis that 
allows us to observe how the response varies over time. We explore several types of health shocks in our analysis.

We have a number of principal findings. First, there are large changes in asset holdings with age. The ownership rates for principal residences and vehicles fall dramatically with age, as do those for other types of assets (though these results are more sensitive to the choice of specification), while the share of total assets invested in bank accounts and CDs rises with age. Second, health shocks play an important role in explaining changes in household portfolios over time. We find that a widow shock is a strong predictor of selling the principal residence, as in the previous literature, but that widow shocks also decrease ownership of vehicles, businesses, and real estate and increase the share of assets held in bank accounts and CDs. Moreover, we find that other health shocks have similar and equally strong effects on household portfolios. Finally, we find that the responses to health shocks are highly dependent on households' physical and mental capacity.

\section{LITERATURE REVIEW}

Our work builds on three literatures. The first concerns portfolio allocation across the lifecycle. The theoretical literature in this area, which dates back to the 1960s, established that under certain assumptions the optimal household portfolio does not vary with age. ${ }^{2}$ There is an empirical literature examining lifecycle patterns in portfolios in the U.S., but it generally does

\footnotetext{
${ }^{2}$ Early papers in this literature include Samuelson (1969) and Merton (1969). Subsequent analyzes have shown how relaxing the assumptions made in these early papers may alter their key conclusion. See Gomes and Michaelides (2005) for a survey of recent research on the correspondence between theoretical models of lifecycle asset allocation and empirical evidence on household portfolios.
} 
not focus on the elderly. ${ }^{3}$ Furthermore, most of these studies are based on a single cross-section, which requires the authors to assume that there are no cohort effects. One exception is Poterba and Samwick (2001), who use pooled cross-sections from the Survey of Consumer Finances; they find that there are large differences in the age-paths for different asset classes and that these paths vary substantially across cohorts.

Despite the relative lack of evidence on this topic in the US, there is a growing international empirical literature on the portfolio allocation of older households. Volumes by Guiso, Haliassos, and Jappelli (2002) and Börsch-Suppan (2003) provide little evidence that the elderly draw down their assets substantially during retirement, but there is evidence of reallocation across asset categories as households age. Milligan (2005) looks at household portfolios in Canada using three cross-section wealth surveys. He uncovers evidence that elderly households do not sell their houses or vehicles until late in life, and suggestive evidence that liquid assets increase with age. Our paper contributes to this literature by using the Health and Retirement Study to document the age-paths for asset holdings of the elderly in the U.S.

The second relevant branch of the past literature looks at the special role of housing in the financial decisions of the elderly. Many studies have found that elderly households are unlikely to consume their housing equity, including Venti and Wise $(1989,1990,2002)$ and Feinstein and McFadden (1989). Skinner (1996) does find evidence that housing wealth is consumed, although this is more prevalent among younger households. Venti and Wise (1989) demonstrate that moving is best predicted by a severe shock such as the death of a spouse and find that transactions costs - broadly conceived to include the psychic costs of leaving behind familiar

\footnotetext{
${ }^{3}$ One exception is Hurd (2002), who looks at asset holdings of older households by five-year age groups. However, he makes no attempt to disentangle the effect of age from cohort effects and survivorship bias, as we do in our empirical analysis, discussed further below.
} 
people and surroundings - play a significant role. Our work contributes to this literature by showing how housing equity fits into the portfolios of elderly households and how health shocks other than the death of a spouse affect both housing and other asset choices.

The third literature that is relevant for our work investigates the effects of health on portfolio decisions. Several studies have examined how changes in health affect total assets. Feinstein and Ho (2001) note the strong predictive power of the death of a spouse on drawdowns of total wealth. Wu (2003) finds key gender differences, as men's health problems lead to more caregiving by wives but women's health problems lead to more wealth decumulation. Hurd (2002) is more similar in spirit to our analysis, as he looks at the effect of transitions from being married to single on the holding of various asset classes. Our work is distinguished from his by virtue of looking at the effect of other health shocks in addition to widowhood, looking at the long-term as well as immediate response, including household fixed effects, and exploring reasons why households reallocate their portfolios in response to shocks. Finally, Rosen and $\mathrm{Wu}$ (2004) find that households in poor health are less likely to own risky assets than other households. However, their analysis is based on a cross-section, raising the possibility that poor health is correlated with unmeasured characteristics that affect portfolio allocation. By looking at a wider variety of health shocks, examining their effect on multiple asset categories, and exploring the dynamic nature of and some reasons for the response to shocks, our work allows us to draw more precise conclusions about the effects of health on portfolio choices.

\section{DATA AND EMPIRICAL STRATEGY}

In this analysis, we use the Health and Retirement Study (HRS). The HRS began in 1992 as a survey of individuals born 1931-1941 and their spouses, with re-interviews of these 
individuals every two years. In 1998, the HRS was expanded through a merger with the Study of Assets and Health Dynamics among the Oldest Old (AHEAD), which had interviewed households born before 1924 in 1993 and 1995. At the same time, the survey added two new cohorts, the Children of the Depression (CODA, born 1924-1930) and the War Babies (WB, born 1942-1947). In total, the enhanced HRS had nearly 22,000 respondents in 1998 and continues to interview these individuals every other year. We use the first six waves of the HRS, 1992-2002.

The HRS is extremely well-suited for our purposes because it contains detailed information on assets and health and follows the same older households over time. For most analyses, we use data on all households for all waves they participate in the sample; thus, each household may provide up to 6 observations if from the original HRS cohort, 5 if from the AHEAD cohort, and 3 if from the CODA and WB cohorts. ${ }^{4}$ We use the RAND version of the HRS, a user-friendly subset of the HRS with cleaned and consistent variables. Of particular note, we use RAND's model-based imputations for any missing wealth data.

Our analysis proceeds in two parts. First, we explore how wealth evolves with age, looking at five asset categories: principal residence; vehicles; financial assets including stocks, bonds, and Individual Retirement Accounts (IRAs); bank accounts and CDs; and business and other real estate. ${ }^{5}$ We start with a simple cross-sectional analysis of wealth holdings by category

\footnotetext{
${ }^{4}$ AHEAD data from 1993 and 1995 is treated as having been collected at waves 2 and 3, respectively; thus, there is no wave 1 observation. As detailed below, some analyses are conditioned on remaining in the sample through 2002 or are limited to certain age groups only. Because we have differing numbers of observations for each household in the panel, our strategy results in an unbalanced panel. The primary econometric issue arising with unbalanced panels is with non-random selection and attrition. However, duration in our panel is primarily determined by the wave in which the household begins taking part in the HRS, so it is largely unrelated to individual characteristics (besides birth cohort) .

5 "IRAs" includes all funds in Individual Retirement Accounts or Keoughs. "Stocks" includes stocks, mutual funds, and investment funds. "Bonds" includes bonds and bond funds. "CDs" includes certificates of deposit, savings bonds, and t-bills. "Other savings," which we include on Table 1, includes items such as jewelry, money owed to
} 
and age using the 2002 HRS. However, differences by age in such an analysis may also reflect cohort and time effects and be tainted by survivorship bias, as wealthy individuals tend to live longer. We begin to address these concerns by graphing the evolution of asset holdings over time for the same HRS individuals. Finally, we formalize this analysis by regressing asset holdings on age. To the basic regression specification shown below we add cohort dummies and then household fixed effects, accounting for any time-invariant unmeasured effects and biases.

Our basic regression using data for household $i$ in time period $t$ takes the form:

$$
\text { Asset holdings }_{i t}=\beta_{0}+\beta_{1} \text { age }_{i t}+\beta_{2} X_{i t}+\gamma_{t}+\varepsilon_{i t} \text {, }
$$

where Asset holdings $s_{i t}$ is a measure of the household's holdings in a particular asset class, age $e_{i t}$ is the age of the household, $\mathrm{X}_{i t}$ is a set of control variables, and $\gamma_{t}$ is a set of wave dummies. The control variables include dummy variables for marital status (widowed, married, or divorced/ separated), region, religion, race, Hispanic status, being US born, and educational category. ${ }^{6}$ Here and elsewhere in the paper we measure the age of the household by taking the age of the older spouse. While the linear age specification is very simple, it will provide some indication of which assets vary strongly with age. ${ }^{7}$ Throughout our analysis, we examine three measures of asset holdings: positive holdings of the asset class, share of total assets in the asset class, and dollar value of assets in the asset class. ${ }^{8}$ We do so for the five asset classes listed above.

the respondent by others, a collection for investment purposes, rights in a trust or estate where the respondent is the beneficiary, or an annuity.

${ }^{6}$ Within the set of control variables, there is also a dummy variable equal to one if the financial respondent has changed since the previous wave, in the event that this has any systematic effect on reports of asset holdings. This is the only control variable that is included in the specification with household fixed effects.

${ }^{7}$ We also tried a quadratic specification. Those results are discussed later in the paper with the discussion of the linear results.

${ }^{8} \mathrm{We}$ are aware that there may be significant measurement error in the dollar value in each asset class, since wealth data are notoriously noisy; this may also affect the share in each asset class, albeit likely to a lesser extent since the share must lie between 0 and 1. For this reason, we present results first for the ownership of each type of asset, 
In the second part of the analysis, we explore how health shocks affect asset holdings.

We use several definitions of a health shock: 1) becoming widowed; 2) experiencing an "acute event" (heart attack, stroke, or new cancer diagnosis), and 3) receiving a new diagnosis of a chronic illness (high blood pressure, diabetes, lung disease, psychological problems, or arthritis). ${ }^{9}$ In all cases, we treat the household as experiencing a shock if either spouse receives a shock.

To begin our analysis of the effect of health on portfolio allocation, we add health shock dummies to the richest version of our first regression model, which incorporates household fixed effects, to obtain regressions of the following form:

$$
\text { Asset holdings }_{i t}=\beta_{0}+\beta_{1} \text { widow }_{i t}+\beta_{2} \text { acute }_{i t}+\beta_{3} \text { chronic }_{i t}+\text { age }_{i t}+\alpha_{i}+\gamma_{t}+\varepsilon_{i t}
$$

Here widow $_{i t}$ is a dummy equal to 1 if household $i$ has experienced a widow shock in period $t$ or an earlier period in our sample and acute $_{i t}$ and chronic $_{i t}$ are similarly defined. In effect, this compares those household-wave observations after a shock to observations before a shock or observations of households who never experience a shock. ${ }^{10}$

Equation (2) gives us some sense of the effect of health shocks on household portfolios, but gives no sense of the dynamics of this process over time. We therefore also estimate regressions of the form:

which is much less likely to be subject to error. We also acknowledge the contribution of Rohwedder et. al. (2004) in noting that changes in wealth holdings between the 1993 and 1995 AHEAD survey are due in part to survey design. We have experimented with dropping the affected observations from the analysis and our results are not substantively different.

${ }^{9}$ More discussion of the latter two health shocks definitions can be found in Coile (2004).

${ }^{10}$ We choose to have the shock variables correspond to having ever experienced a shock rather than to experiencing a shock in this period since the effect of a shock is likely to persist into future periods. We include all three shocks in the same specification to allow for the possibility that households may experience multiple shocks during the full sample period; indeed, about one-fifth of households who experience any health shock during our sample period have more than one shock during the observed period. 


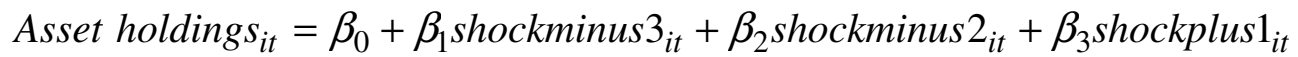

$$
\begin{aligned}
& +\beta_{4} \text { shockplus }_{i t}+\beta_{5} \text { shockplus }_{i t}+\beta_{6} \text { age } e_{i t}+\alpha_{i}+\gamma_{t}+\varepsilon_{i t}
\end{aligned}
$$

In this case, we estimate models separately for each health shock and restrict the sample to those households who experience the shock at some point during the observed sample period. ${ }^{11} \mathrm{We}$ consider the shock to have occurred between periods, so that the shockplus $1_{i t}$ is a dummy equal to 1 if the household-wave observation corresponds to the wave immediately after the shock, and the other shockplus and shockminus variables are similarly defined. The wave immediately before the shock, shockminusl, is the omitted category. This specification allows us to see whether there is any change in asset holdings prior to the shock and whether the response to the shock occurs immediately or later.

\section{RESULTS FOR AGE PATTERNS OF HOUSEHOLD ASSET HOLDING}

Table 1 provides a cross-sectional analysis of household asset holdings by age in the 2002 HRS. ${ }^{12}$ The top panel indicates how the rate of ownership of various assets evolves with age and it reveals some interesting patterns. Home ownership is flat at $80 \%$ until age 80 , but then drops consistently in every successive age group, to a rate of $54 \%$ in the age 90 and above group. Vehicle ownership displays a similar pattern of being relatively flat until age 80 and falling dramatically thereafter, from $82 \%$ in the age $75-79$ group to $40 \%$ in the age 90 and above group. Three other asset categories - other real estate, business, and other savings - start at a lower level, but in all cases asset ownership is cut in half between the 60-64 age group and the 90 and

\footnotetext{
${ }^{11}$ To test for the possibility that observed changes in asset holdings before or after a health shock might be attributable to another health shock the household had experienced (e.g., an acute shock that preceded the widow shock), we have added to this specification dummy variables for whether the household has experienced either of the other health shocks. We find that our results are robust to the inclusion of these variables.

${ }^{12}$ Data are weighted by HRS household weights; age patterns in unweighted data are largely similar.
} 
above age group. IRA ownership falls dramatically after age 70 , no doubt due to the automatic withdrawal provisions. On the other hand, ownership of CDs and bonds rises over time, perhaps due to the greater liquidity or lower risk properties of these assets. Stock and bank account ownership are essentially flat with age.

The other two panels on Table 1 display the share of total assets in each category and the median value conditional on holding the asset. The assets experiencing a drop in ownership with age in the top panel also experience a slide in asset share. In the case of homes and vehicles, the median value conditional on holding the asset also falls over time. Asset shares rise with age in stocks, bonds, CDs, and bank accounts; the increase in the bank account share is particularly dramatic, rising from $10 \%$ at ages $60-64$ to $28 \%$ in the oldest age group, while CDs also rise sharply, from $2 \%$ to $10 \%$. The median value of total assets falls considerably starting at age 80 , potentially reflecting some dissaving to finance retirement consumption.

As noted above, however, there are several potential problems with this analysis. Observed patterns may reflect cohort or time effects as well as age effects. Moreover, since wealthier households are more likely to survive, observed patterns may reflect the selection of a wealthier sample in the higher age groups.

To begin to address these concerns, we conduct a cohort-based analysis that tracks asset holdings of the same households over time. Specifically, we divide the sample into 20 groups, each of which consists of two single birth cohorts (e.g., 1931-1932). Depending on whether the group is part of the original HRS, AHEAD, WB, or CODA cohorts, households appear in the survey 3 to 6 times. We drop households that do not stay in the survey for all waves where they might be observed, to avoid having the composition of the group change over time as households 
leave the survey due to death or attrition; however, we acknowledge that older cohorts may still be wealthier due to differential mortality.

Figures 1a-1e display the results of this analysis. Each of the short lines on a graph represents the asset holdings for a particular group at the ages they are observed. So,for example, the 1931-1932 group, which is part of the original HRS cohort, appears in all 6 waves of the survey and contributes information for ages 60-61, 62-63, etc. through 70-71. Any given line shows the effect of aging for a fixed sample of households; if the various lines that cover the same age range are close together, this will indicate that cohort effects are small, at least for cohorts that are relatively close together.

The graphs largely confirm that the results from Table 1 remain when we do a better job of controlling for cohort effects and survivorship bias. Home and vehicle ownership rates fall dramatically after age 80 , with the slide in vehicle ownership clearly visible at much younger ages as well. There is also a steady decline in the business and other real estate ownership rate starting at age 60. Ownership of bank accounts and CDs are roughly flat, with perhaps a small decrease at the oldest ages. Ownership of financial assets (IRAs, stocks, or bonds) is declining over time, driven primarily by a steady drop in IRA ownership, though there is a small drop in stock ownership as well. Figure 1c is the one case where cohort effects are apparent - the AHEAD cohorts are significantly less likely to own IRAs, stocks, and bonds.

We now turn to some basic regression analysis to document more precisely the trends observed in the figures. The goal of this analysis is to provide some preliminary evidence on which assets are most sensitive to aging, in order to guide our analysis with the health indicators later in the paper. Table 2 contains regression results for the sample of households-wave observations in which the older spouse is age 60 or above. We provide results for the five asset 
classes and three asset holding measures (positive asset value, share of total portfolio, and asset value), with the three econometric specifications discussed above (no fixed effects, cohort fixed effects, and household fixed effects). The regressions are estimated by OLS, with robust standard errors clustered to account for repeated observations on the same cohorts and households.

The first column of the table shows the results from a specification with a linear age term and no controls for cohort or individual fixed effects. ${ }^{13}$ This specification most closely aligns with the simple analysis in Table 1 , since no attempt is made to disentangle the age from the cohort effects. The dependent variable in the first panel of results, asset ownership, is binary, so the coefficient can be interpreted as a change in the probability in owning the asset for an additional year in age. For example, the first reported coefficient for ownership of a principal residence is -0.0048 . This coefficient suggests that as a household becomes one year older, the probability that they own a home will decline by 0.48 percentage points. Given the mean of 0.756, this linear coefficient suggests a 6.3 percent (or 4.8 percentage point) decline in the probability of ownership over a decade. ${ }^{14}$ The coefficients for the other asset categories are also negative and highly significant, with the business and real estate coefficient being the largest in percent terms - the coefficient suggests a 15.1 percent (or 3.3 percentage point) decline in the probability of ownership over a decade.

In the second column of the table, we add a set of dummy variables for the year of birth cohort to which each household belongs. This specification effectively compares household-

\footnotetext{
${ }^{13}$ Results for the quadratic specifications revealed similar patterns to the linear specifications. For vehicle ownership, for example, the marginal effects of the quadratic coefficients implied that ownership trends turned negative around age 69, and approached the linear effect in the 80s.

${ }^{14}$ We tried probit specifications to see if accounting for the binary dependent variable with a nonlinear estimator mattered. We obtained similar point estimates for the marginal probabilities. For example, the estimate on principal residence was -0.0049 , compared to the -0.0048 in the linear specification.
} 
wave observations of different ages within the same year-of-birth cohort, allowing the effect of age to be separated from the effect of cohort. ${ }^{15}$ Many of the coefficients become smaller in this specification, with the strongest results remaining for the principal residence and financial assets.

The final column of Table 2 provides the results using household fixed effects. In this specification, the age coefficient is identified by variation within each household over time, exploiting the panel structure of the data. In comparing the linear age, cohort fixed effect, and household fixed effect specifications, the usual trade-offs apply - the specifications with cohort and household fixed effects likely do a better job of controlling for unobservable heterogeneity, but there is a risk of being left with too little variation to estimate statistically significant relationships. The principal residence result holds up to this fixed effect specification. In addition, the extensive margin variable for vehicles again becomes large and statistically significant. The coefficient showing the effect of age on financial asset ownership becomes statistically insignificant.

The second panel of Table 2 shows the effect of age on the share of the household's portfolio held in a particular asset class. Because the shares must sum to one across the asset categories, an increase in one category must necessarily lead to a decrease in another. ${ }^{16}$ For this reason, we expect to find some positive coefficients for this set of results, in contrast to the positive holdings and dollar value results.

\footnotetext{
${ }^{15}$ Observations on households of different ages from the same year-of-birth cohort will necessarily be taken at different points in time. Thus there is the possibility that differences in asset holdings reflect not only age effects but also time effects (e.g., observations from 1998 will have experienced a higher recent rate of return on their stock assets than observations from 1994). As is well known, even with longitudinal data there is no way to separately identify age, cohort, and time effects. We assume that time effects are likely small, particularly with respect to asset ownership.

${ }^{16}$ Recall, however, that we do not report results for the 'other savings' category. The share coefficients for this variable were typically positive, but not very large in magnitude.
} 
In the first specification without cohort or household fixed effects, age is associated with a reduction in the share of assets invested in principal residence, vehicles, financial assets (IRAs, stocks, and bonds), and business or real estate and is associated with an increase in the share of assets invested in bank accounts and CDs. All coefficients are highly significant. The second and third columns display the results of incorporating cohort and household fixed effects. The results in the second column are comparable to those in the first column, with the exceptions of the vehicle and business and real estate shares. The results that hold up across all three specifications are the principal residence and the positive coefficient on bank accounts and CDs. The coefficients imply sizeable effects of age on asset allocation over the long-term. For example, over a 20-year period, the share held in bank accounts and CDs is projected to increase by 6.2 percentage points, or 31 percent relative to the average share in the sample.

The bank account share result is intriguing. Bank accounts are dominated by other assets on a risk-return basis, yet there is an increasing proportion of household assets devoted to them with age. This finding resonates with earlier results for bank accounts found in Milligan (2005) in a cross-section and Poterba and Samwick (2001) in stacked cross-sections. Extending these results to our panel-data setting allows us to verify that the finding remains even after controlling for cohort and individual fixed effects.

There are several potential explanations for this finding. It may be a transitory result as windfalls of insurance money, pension lump sums, or proceeds from the sales of housing pass through bank accounts on their way to other asset classes. Alternatively, it may be that the complexity of financial arrangements leads seniors, particularly those with diminished mental or physical capacity, to select portfolios that are easier to manage. We investigate these possibilities later in the paper. 
The third panel shows the effect of age on the dollar value invested in a particular asset class. In the first column, the results are broadly similar to those in the second panel. The dollar value invested in all asset classes falls with age, except for bank accounts and CDs, whose value rises with age. For the cohort fixed effect and household fixed effect models, the larger standard errors indicate that few precise inferences can be made.

This regression analysis has revealed several important findings. First, the relationship between asset holdings and age is affected by the inclusion of cohort fixed effects or household fixed effects. Second, we find a negative relationship between age and the probability of holding all types of assets; in the case of principal residence and vehicle ownership, the negative relationship persists even in the household fixed effects model. Finally, we find a strong and persistent effect of increasing share of assets in bank accounts and CDs as the households become older.

Taken together, this evidence indicates behavior that is more discrete than suggested by simple models of lifetime portfolio allocation. Moreover, aspects other than risk and return seem to be important for decisions surrounding primary residences, vehicles, and bank accounts. An obvious candidate to explain some of this behavior is changes in the health condition of the household. We pursue this analysis in the next section.

\section{RESULTS FOR THE EFFECT OF HEALTH SHOCKS}

Could health shocks help to explain the age-trends in asset decisions observed in Table 2? Figure 2 graphs the incidence (over a two-year period) by age of the three health shocks we consider. Because our asset data is at the household level, we consider a shock to have hit the household when either member of the couple experiences the change in health. In the 60 s, the 
shock with the highest incidence is the diagnosis of new chronic illnesses, peaking at 6.8 percent at age 76; by the mid-to-late 80s, the incidence of new chronic illnesses has fallen sharply. The incidence of acute shocks is fairly constant over time, at about 2 to 4 percent of the sample at each age. For widowhood, the probability of suffering a shock increases from less than 3 percent at age 60 to over 6 percent at age 80 . Overall, this figure demonstrates the relatively high incidence of health shocks for the elderly.

More striking than the period-by-period rate of incidence is to look at how many households last until age 89 without suffering a shock. For widowhood, only $28.2 \%$ of households survive to 89 without one or the other partner dying. The magnitude of these numbers suggests that changes in asset holdings could conceivably be related to health shocks.

To more rigorously examine the link between the health shocks we graphed in Figure 2 and the asset changes we graphed in Figures 1a-1e, we next estimate regressions based on equation (2). These results are provided in Table 3. In the first column of the upper panel, we show that being widowed is associated with a sharp decrease in the probability of owning a principal residence or car. Households who have experienced widowhood are 4.2 percentage points (or 5.6 percent, relative to the average home ownership rate of 76 percent) less likely to own a home and 7.4 percentage points (9.4 percent) less likely to own a vehicle. These effects are highly significant. The same responses are seen when we look at the share of holdings or dollar values in each asset class.

Another interesting result from Table 3 is that experiencing an acute shock is associated with a decrease in both the probability of owning a business or real estate and the share of assets held in that asset class. For chronic illness, there is some evidence that the shock affects the 
probability of holding various assets, but no significant effects on the share of holdings or dollar values in each asset class.

The results from Table 3 on the effect of widowhood on home ownership are in line with the previous literature. We augment previous studies by looking at numerous asset classes and controlling for multiple health shocks simultaneously. But our analysis is quite simple, in that we compare household-wave observations after health shocks to those before or those who do not experience the shock. A dynamic analysis may provide a richer picture of how households reallocate their portfolios over time following health shocks.

To pursue this, we turn to the dynamic analysis laid out earlier in equation (3). For this analysis, we select the sample for each shock by choosing any household in which one member of the couple experiences the shock between one HRS wave and the next. We then use the panel structure of the data set to observe their asset choices several periods before and after the onset of the shock. For some households, we might see a shock occur between waves 1 and 2 . For that household, we would observe one 'pre-shock' period and several 'post-shock' periods. For other households, we might observe a shock between waves 5 and 6 . For that household, we could observe up to five 'pre' periods (waves 1 to 5) as well as one period after the shock. In practice, we limited the sample to three periods before and three periods after the shock. Across all the households in the sample, therefore, we can develop a very complete picture of the effect of health shocks on asset decisions both before and after the onset of a shock. ${ }^{17}$

The coefficients reported on Table 4 are for the dummy variables indicating the distance in periods (of two years each) from the shock period. The omitted category is the period just before the shock occurred, so all of the coefficients should be interpreted as the change in the probability of holding positive values of the asset category relative to the period before the

\footnotetext{
${ }^{17}$ Including extra periods beyond the $-3 /+3$ window does not change the results.
} 
shock. We also report the mean of the dependent variable for each asset class, which corresponds to the proportion of the sample that holds a positive value of the asset.

We begin with an analysis of the widow shock in the top panel of Table 4 . This marks a sensible starting point because earlier research by Venti and Wise (2002) highlights the importance of widow shocks on housing changes. As in Table 3, there is a sharp drop in ownership of both principal residences and vehicles following the death of one of the spouses. For the principal residence, the drop in ownership is 4.6 percentage points in the first period after the shock, and the effect is fairly constant over time. This represents a 6 to 7 percent drop from the mean ownership rate of 76 percent. For vehicles, the drop is estimated to be 8.6 percentage points in the first period after the shock, rising to 12.7 points three periods after the shock; since there are two years between waves, three periods after the shock corresponds to about 6 years. This 12.7 point drop represents 16 percent of the 80 percent average vehicle ownership rate. Interesting, a pre-existing trend towards reduced vehicle ownership is evident even before the widow shock. ${ }^{18}$

Another interesting result from the top panel of Table 4 is that widowhood is associated with an increased probability of owning a bank account or CD. The effect is 2.5 percentage points in the first period and grows to 4.9 percentage points three periods after. This indicates that the shift into these assets is not temporary, but rather marks a long-lasting move into assets that offer a low return but also low risk, and in the case of bank accounts, high liquidity. This dismisses the possibility raised earlier that the move into bank accounts is a transitory step before wealth is redeployed elsewhere. There is also a strong effect of widowhood on the probability of

\footnotetext{
${ }^{18}$ This is evident even when we control for the presence of other health shocks in the household, such as an acute event that preceded the widow shock. One possible explanation is that these controls don't pick up the severity of the other shock or that there are some households in which the other shock occurred before the beginning of our sample period and thus is not observed.
} 
owning a business or real estate: widowhood reduces this probability by 6.9 percentage points three periods after the shock, or 37 percent relative to the 19 percent average ownership rate of these assets. As with vehicles, a pre-existing trend is evident.

The second and third panels of Table 4 examine the effect of chronic and acute shocks on having positive holdings in a particular asset class. The effects of the two types of shocks are quite similar. Both eventually lead to significant drops in the ownership of principal residence a 4 percentage point drop in the case of a chronic shock and a 5.7 percentage point drop in the case of an acute shock three periods after the shock. Unlike the widow shock, however, the response is not immediate, indicating that these shocks may foretell future health deterioration that will eventually force a sale. There is a large drop in vehicle ownership as well, which is evident one to two periods after the shock.

There is also a significant effect of chronic and acute shocks on the probability of owning a business or real estate that appears immediately and grows to be quite large by three periods after the shock. It appears that following such a shock, it becomes increasingly difficult for the household to manage this type of asset. There is a decrease in ownership of IRAs, stocks, and bonds following a chronic shock, indicating that households may draw upon these assets as health deteriorates. In the case of chronic shocks, there is some evidence of pre-existing trends, suggesting that for some households there may be measurement error in the timing of the shock, with symptoms commencing before a diagnosis is made. There is no evidence of this for an acute shock, which seems sensible given that this measure is comprised of health events that would presumably come on more suddenly, such as a heart attack or stroke.

On Table 5, we look at the effect of the three shocks on the share of household assets invested in each asset class, which allows us to consider portfolio reallocations on the intensive 
as well as extensive margin. ${ }^{19}$ The most notable new result is a significant increase in the share of assets in bank accounts and CDs as a result of all three types of shock. For a chronic shock, for example, the effect is a 3.5 percentage point increase three periods after the shock, or 23 percent relative to the mean share of 15 percent. Many of the other results are what would be expected based on Table 4, such as the decrease in business and real estate investments following chronic and acute shocks, though surprisingly the effects of those shocks on the share of assets invested in a principal residence are small and statistically insignificant.

It is clear from Tables 4 and 5 that households make substantial changes to their portfolios following health shocks, but the reasons why households make these changes are less clear. We explore this question in Table 6. For simplicity, we focus on the widow shock, which is where some of the biggest changes in portfolio allocation seem to occur. We select some of the asset holding measures where the biggest changes were evident: ownership of principal residences, vehicles, and business or real estate, and share invested in bank accounts and CDs. In each case, we estimate a model with dummy variables for periods before and after the shock, as in Tables 4 and 5, but we also interact these period dummies with measures of physical, mental, and financial capacity that may influence the household's response. The measures we use are: a dummy indicating that the household has difficulty with any activities of daily living (ADLs), a dummy equal to 1 if the household reports difficulty in managing money, and a dummy equal to 1 if the household experienced out-of-pocket medical expenses in excess of

\footnotetext{
${ }^{19} \mathrm{We}$ do not present the effect of shocks on the dollar value invested in each asset class in the interest of space and because, as noted above, we face a greater risk of measurement error with this measure than with our other dependent variables. However, results for the dollar value in each asset class are broadly similar to those for the share of assets.
} 
$\$ 5,000 .{ }^{20}$ Our hypothesis is that these factors may strengthen the effect of the health shock, providing some insight as to why households reallocate their portfolios following a shock.

The results of this analysis are shown in Table 6 . We report the coefficients from the main effect for each of the five period dummies along with the interaction of these period dummies with the three measures indicated above. Because there are household fixed effects in the model, the main effects for the three measures are redundant and so drop out of the regression.

In the case of physical and mental capacity, we find that these limitations greatly magnify the effect of a shock. For example, three periods after, the effect of a widow shock is to lower the probability of home ownership by 3.8 percentage points if there is no capacity limitation, but by 13.6 percentage points when there is ADL impairment and by 15.8 percentage points when there is difficulty managing money. The results are even more striking in the case of vehicle ownership, with the effect jumping from 12.9 percentage points to 22.8 points with ADL impairment and 34.9 points with difficulty managing money. Interestingly, for business and real estate, the interaction terms have no effect, indicating that these assets are sold off for other reasons. For the share of assets invested in bank accounts or CDs, these capacity factors are also very important. The base effect of a widow shock is essentially zero, but the effect on the share of assets in bank accounts or CDs jumps to 9.1 points when there is an ADL impairment and 19.9 points when there is difficulty managing money. Thus it seems that responses to shocks are

\footnotetext{
${ }^{20}$ In each case, the value of these measures for the household is fixed at its value in the period immediately after the shock. We have experimented with other measures designed to get at physical, mental, and financial capacity. For ADLs, we tried setting the dummy equal to 1 only if a member of the household had difficulty with multiple ADLs; results were similar. For mental capacity, we also looked at the household members' scores on tests of memory and cognition; these generated similar results, but we chose the ability to manage money because it seemed most relevant here. For financial constraints, we tried a higher dollar cutoff for out-of-pocket medical expenditures, scaling this by income, and simply dividing the sample by household income; results were similarly insignificant. We also tried a variable in the HRS measuring individual risk aversion but found no consistent relationship to asset choices - a finding limited by the fact that the question is only asked in some waves of the survey.
} 
heterogenous, with the tendency to sell homes and vehicles and to put that money in safe, lowreturn, and liquid assets much stronger when widows have physical or mental impairments.

\section{CONCLUSIONS}

In this paper, we explore the effects of aging and health shocks on portfolio allocation of elderly households. Although previous studies have examined some aspects of these relationships, we make several important contributions to this literature. First, we undertake a comprehensive analysis of the effect of age on asset holdings in many asset classes, with a special focus on separating the direct effect of aging from cohort effects or survivorship bias. Second, we examine how health shocks are associated with changes in asset holdings; while many previous studies have focused on the effect of widowhood on home ownership, we expand this analysis to look at other asset holdings and other health shocks and to chart the dynamic path of adjustment to a health shock. Finally, we begin to explore the reasons for responses to health shocks by testing how the response depends on physical, mental, and financial capacity.

On the first question, we document a sharp decline in home and vehicle ownership with age and an increase in the share of assets held in bank accounts and CDs. These effects are robust to the inclusion of household fixed effects. For all other asset classes, we find that the ownership rate and share of assets in the class is declining with age; however, these effects are present only in models with cohort effects.

On the second question, we find that health shocks have significant effects on asset holdings. As has been found in the previous literature, we find being widowed is associated with a significant drop in the probability of home ownership. However, we also document that widowhood lowers the probability of ownership of vehicles, businesses, and real estate and 
raises the share of assets held in bank accounts and CDs. Furthermore, the effects of acute events such as a heart attack or stroke or of the diagnosis of a new chronic illness are very similar.

On the third question, we find that the observed responses to health shocks are many times greater when the respondent has physical incapacity (difficulties with activities of daily living) or mental incapacity (difficulty managing money).

Our results suggest that factors other than standard risk and return considerations may weigh heavily in many older households' portfolio decisions. For example, the finding that the share of assets held in bank accounts and CD rises with age and widowhood and that the effect is stronger for widows with physical impairments or difficulty managing money indicates that households may place more value on liquidity or ease of portfolio management than on the higher returns that could be earned in other financial assets.

In the U.S. today, households are being given more responsibility for saving for retirement and for managing assets during retirement due to the ongoing shift from defined benefit to defined contribution pensions. The possible partial privatization of Social Security could further accelerate this trend. Our findings may be of interest to policy makers seeking to ensure the well-being of vulnerable groups, such as elderly widows, during this time of transition. 


\section{REFERENCES}

Ameriks, John and Stephen P. Zeldes (2002). "How Do Household Portfolio Shares Vary with Age?" TIAA-CREF Working Paper 6-120101.

Börsch-Suppan, Axel 2003. Saving: A Cross-National Perspective. San Diego: Academic Press.

Bucks, Brian, Arthur Kennickell, and Kevin Moore (2006). "Recent Changes in U.S. Family Finances: Evidence from the 2001 and 2004 Survey of Consumer Finances," Federal Reserve Bulletin 92(Feb 2006):A1-A38.

Coile, Courtney C. 2004. "Health Shocks and Couples Labor Supply Decisions." NBER Working Paper No. 10810.

Feinstein, Jonathan S. and Chih-Chin Ho. 2001. "Elderly Asset Management and Health." In Rethinking Estate and Gift Taxation, edited by William G. Gale, James R. Hines, and Joel Slemrod, 457-98. Washington DC: Brookings Institution Press.

Feinstein, Jonathan and Daniel McFadden. 1989. "The Dynamics of Housing Demand by the Elderly: Wealth, Cash Flow, and Demographic Effects." In The Economics of Aging, edited by David A. Wise, 55-86. Chicago and London: University of Chicago Press.

Gomes, Francisco and Alexander Michaelides. 2005. "Optimal Life Cycle Asset Allocation: Understanding the Empirical Evidence," Journal of Finance 60: 869-904.

Guiso, Luigi, Michael Haliassos, and Tulio Jappelli. 2002. Household Portfolios. Cambridge, MA: MIT Press.

Merton, Robert C. 1969. "Lifetime Portfolio Selection under Uncertainty: The Continuous Time Case," Review of Economics and Statistics 51: 247-257.

Milligan, Kevin. 2005. "Lifecycle Asset Accumulation and Allocation in Canada." Canadian Journal of Economics 38(3): 1057-1106.

Poterba, James M. and Andrew A. Samwick. 2001. "Portfolio Allocations Over the Life Cycle." In Aging Issues in the United States and Japan, edited by Seiritsu Ogura, Toshiaki Tachibanaki, and David A. Wise, 65-103. Chicago: University of Chicago Press.

Rohwedder, Susann, Steven Haider, and Michael Hurd (2004). "Increases in Wealth among the Elderly in the Early 1990s: How Much is Due to Survey Design," NBER Working Paper No. 10862.

Rosen, Harvey S. and Stephen Wu. 2004. "Portfolio Choice and Health Status." Journal of Financial Economics 72(3): 457-84. 
Samuelson, Paul. 1969. "Lifetime Portfolio Selection by Dynamic Stochastic Programming," Review of Economics and Statistics 51: 239-246.

Skinner, Jonathan. 1996. "Is Housing Wealth a Sideshow?" In Advances in the Economics of Aging, edited by David A. Wise, 241-268. Chicago: University of Chicago Press.

Venti, Steven F. and David A. Wise. 1989. "Aging, Moving, and Housing Wealth." In The Economics of Aging, edited by David A. Wise, 9-48. Chicago and London: University of Chicago Press.

Venti, Steven F. and David A. Wise. 1990. "But They Don't Want to Reduce Housing Equity". In Issues in the Economics of Aging, edited by David A. Wise, 13-29. Chicago and London: University of Chicago Press.

Venti, Steven F. and David A. Wise. 2002. "Aging and Housing Equity". In Innovations in Retirement Financing, edited by Olivia S. Mitchell et al., 254-281. Pension Research Council Publications. Philadelphia: University of Pennsylvania Press.

Wu, Stephen. 2003. "The Effects of Health Events on the Economic Status of Married Couples." Journal of Human Resources 38(1): 219-30. 
Figure 1a: Home Ownership Rate by Age and Cohort

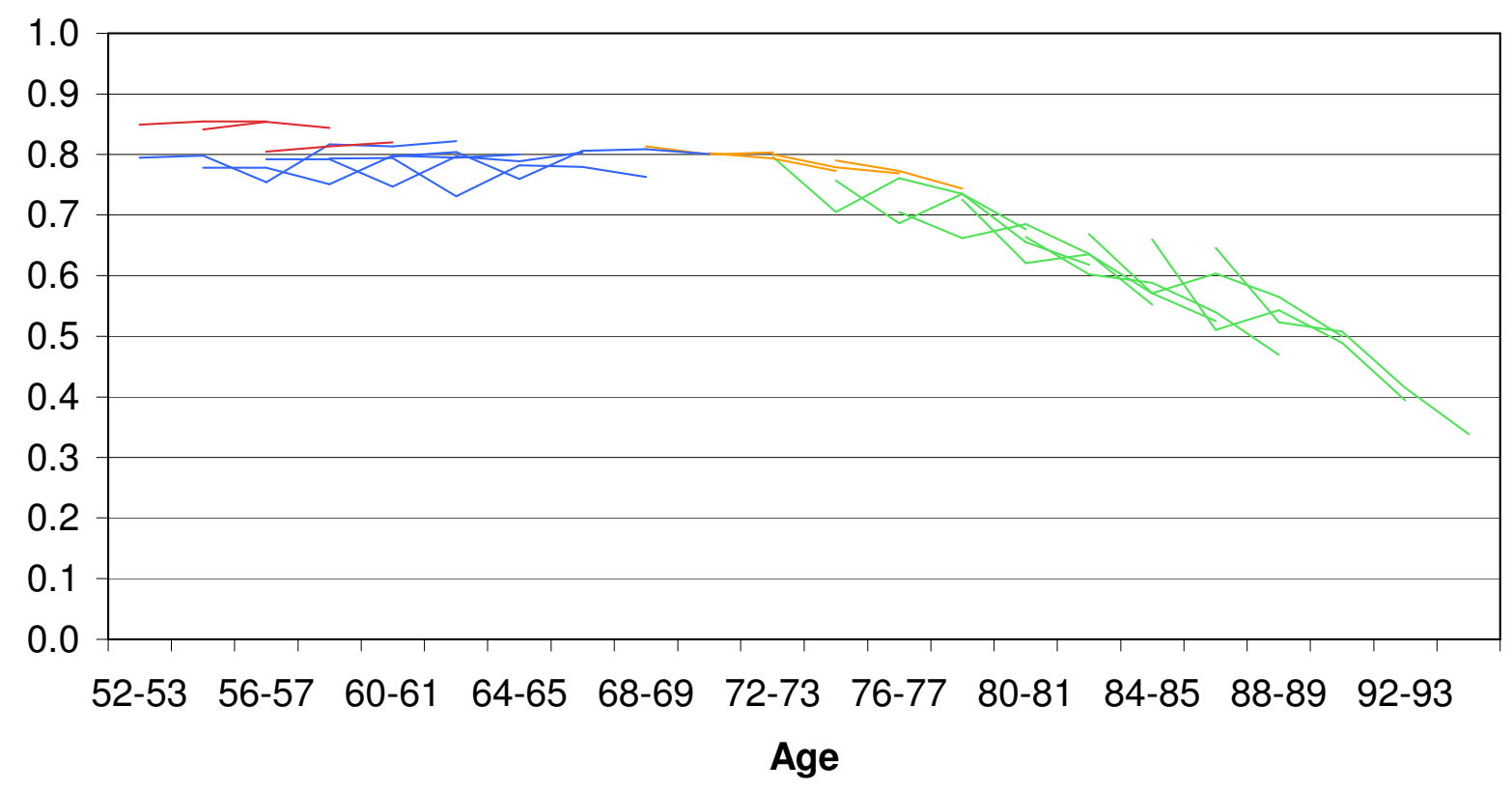

Figure 1b: Vehicle Ownership Rate by Age and Cohort

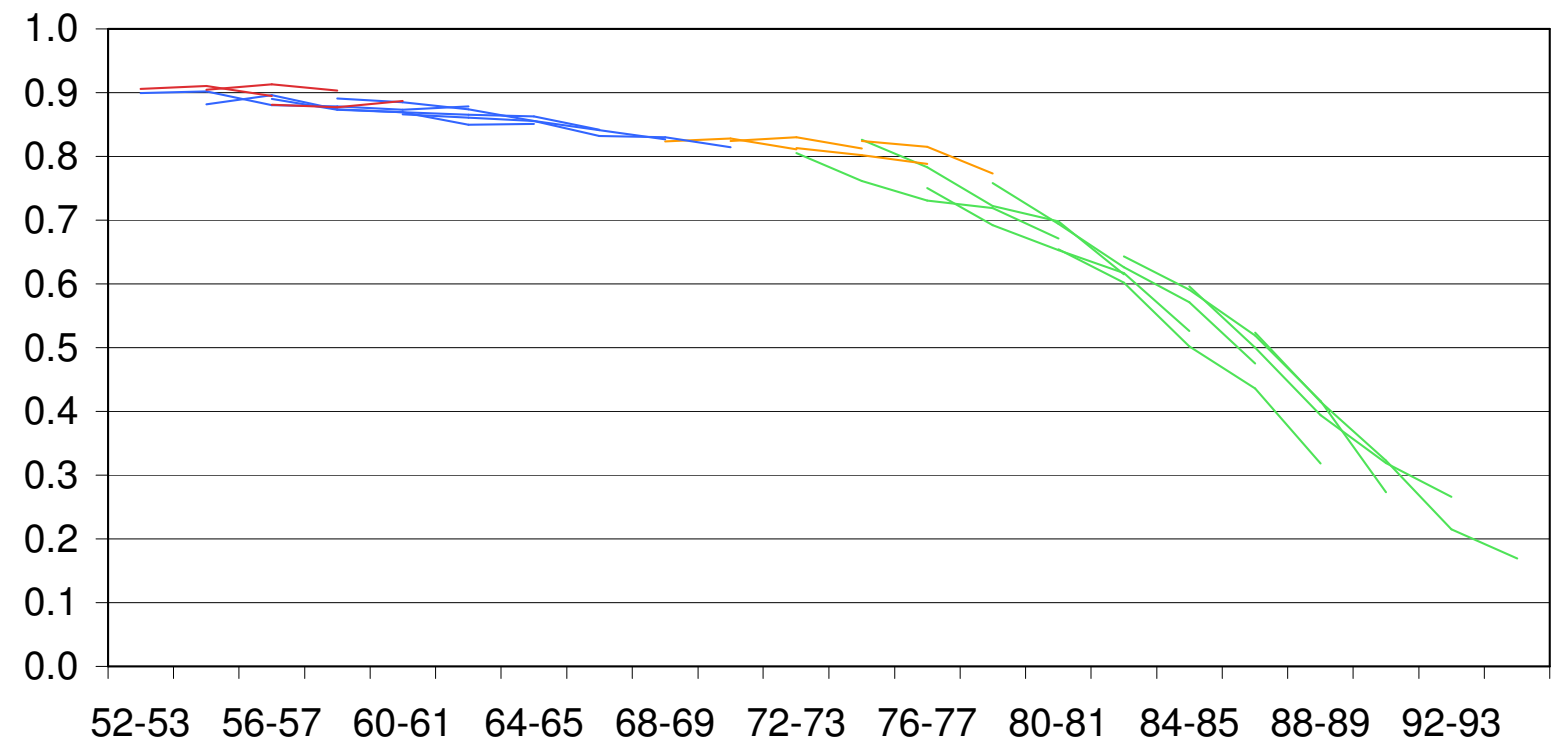


Figure 1c: Ownership of IRAs, Stock, \& Bonds by Age and Cohort

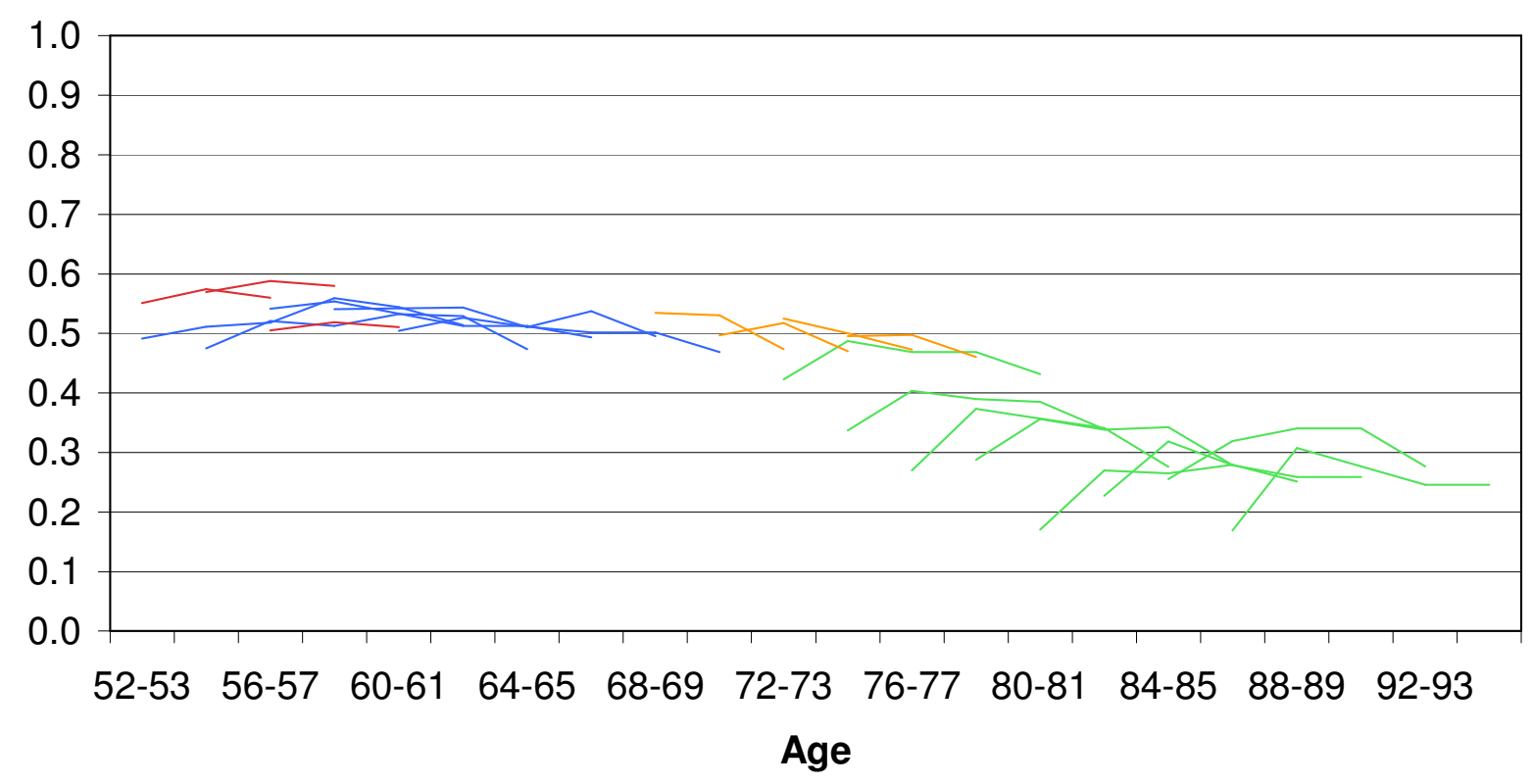

Figure 1d: Ownership of Bank Accounts and CDs by Age and Cohort

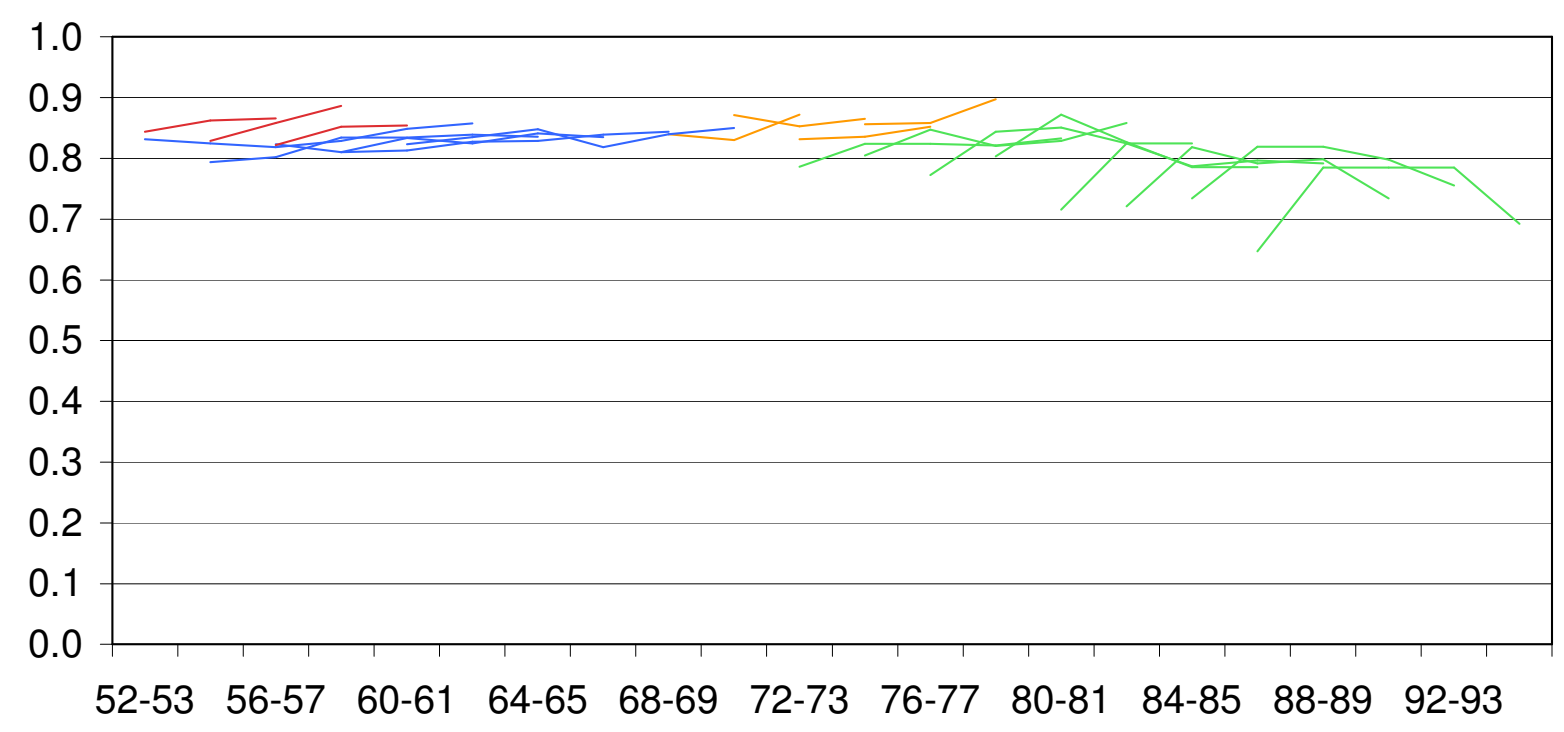


Figure 1e: Ownership of Business and Real Estate by Age and Birth Cohort

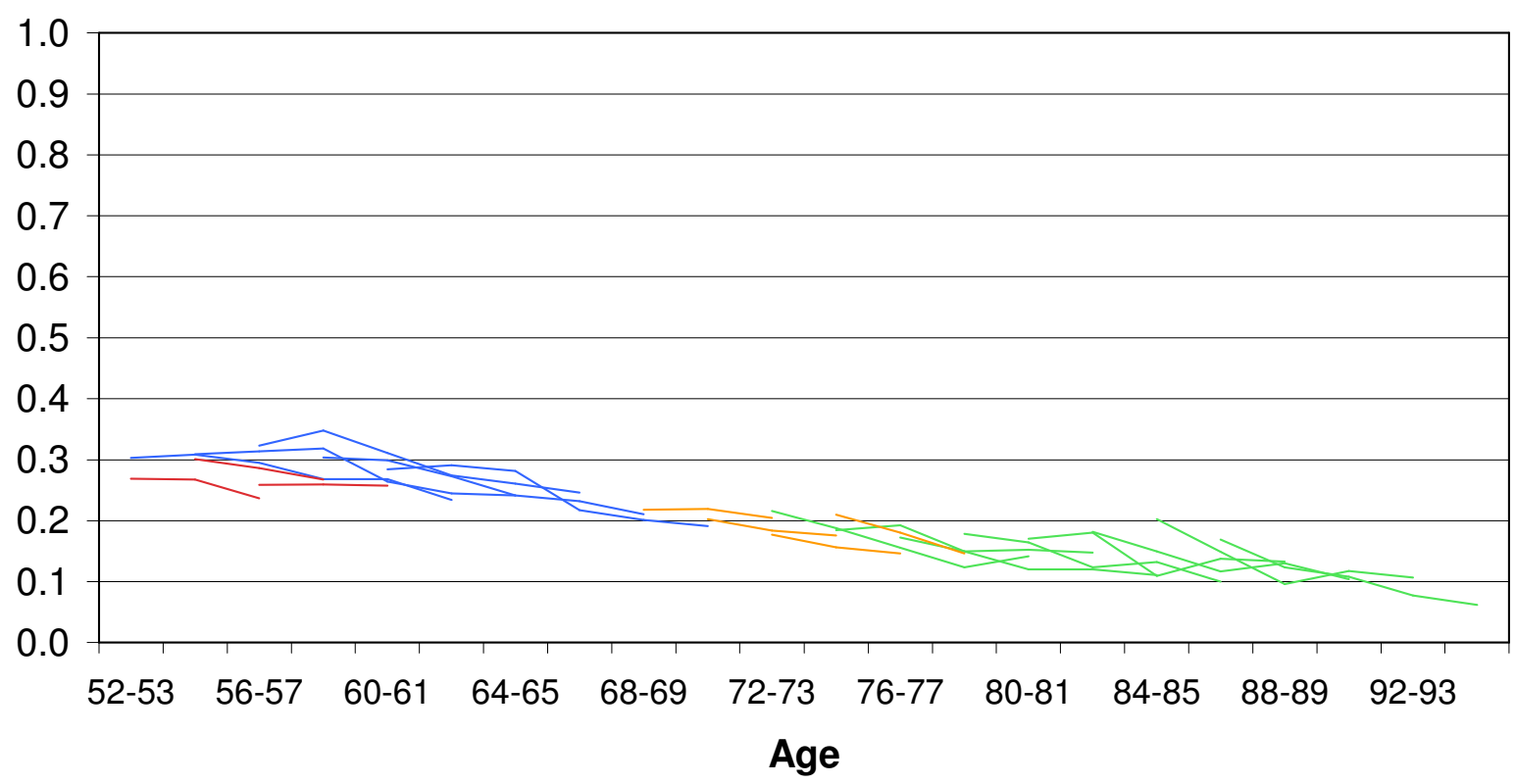

Figure 2: Proportion of Households Suffering Health Shocks by Age

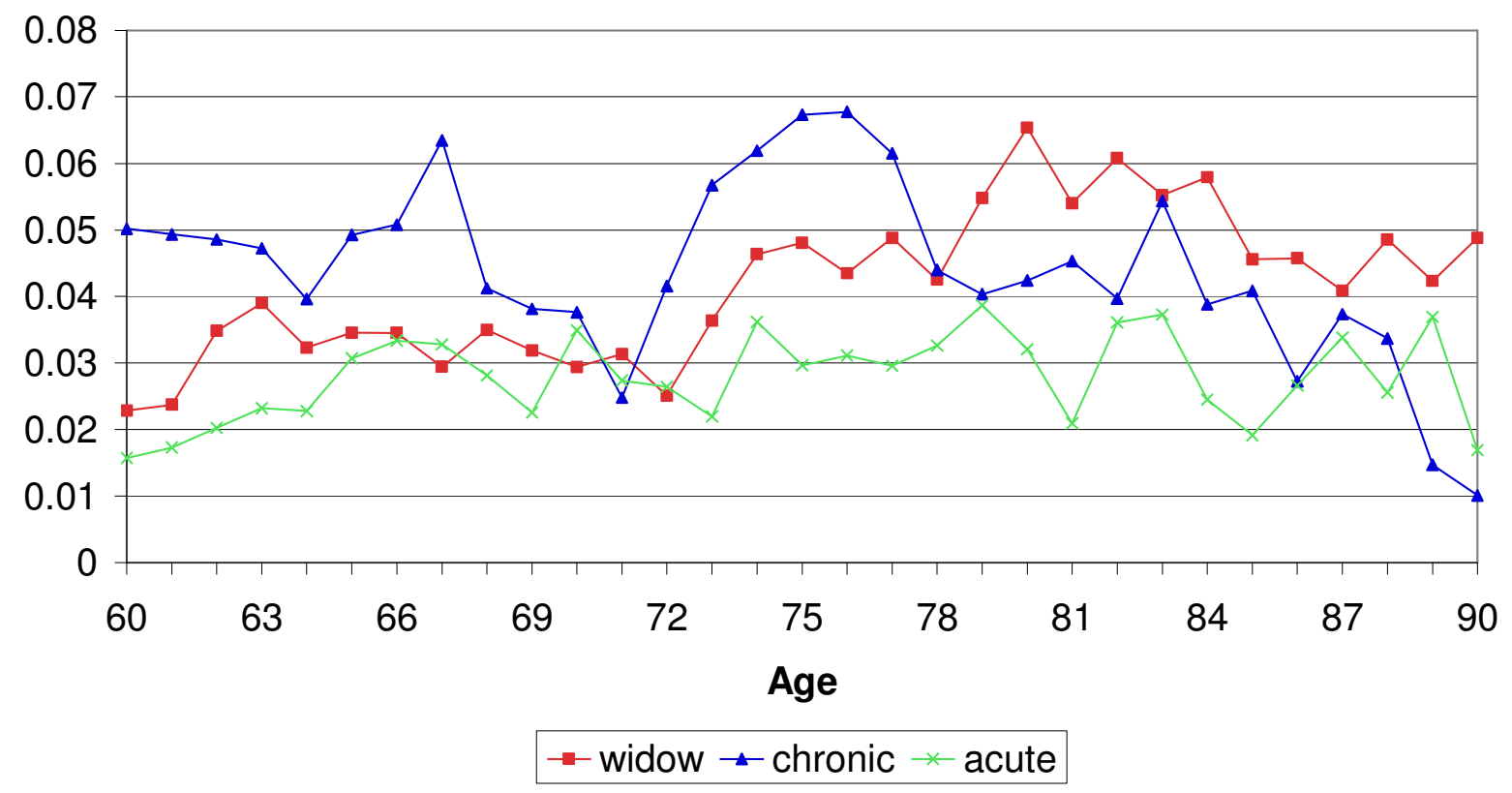


Table 1: Household Assets by Age, 2002 HRS (in \$2003)

\begin{tabular}{|c|c|c|c|c|c|c|c|c|}
\hline \multirow[t]{2}{*}{ Asset Type } & \multicolumn{8}{|c|}{ Age } \\
\hline & $55-59$ & $60-64$ & $65-69$ & $70-74$ & $75-79$ & $80-84$ & 85-89 & $90+$ \\
\hline \multicolumn{9}{|c|}{ \% With Positive Asset Holdings } \\
\hline Princ. Resid. & 0.80 & 0.82 & 0.80 & 0.80 & 0.79 & 0.73 & 0.65 & 0.54 \\
\hline Vehicles & 0.88 & 0.89 & 0.87 & 0.83 & 0.82 & 0.74 & 0.61 & 0.40 \\
\hline IRAs & 0.42 & 0.42 & 0.41 & 0.40 & 0.33 & 0.25 & 0.09 & 0.03 \\
\hline Stocks & 0.35 & 0.33 & 0.33 & 0.31 & 0.33 & 0.31 & 0.30 & 0.29 \\
\hline Bonds & 0.07 & 0.07 & 0.07 & 0.09 & 0.09 & 0.08 & 0.08 & 0.11 \\
\hline Bank Accounts & 0.87 & 0.86 & 0.87 & 0.86 & 0.86 & 0.88 & 0.86 & 0.84 \\
\hline CDs & 0.18 & 0.19 & 0.24 & 0.27 & 0.31 & 0.33 & 0.34 & 0.32 \\
\hline Business & 0.11 & 0.12 & 0.10 & 0.08 & 0.08 & 0.06 & 0.06 & 0.06 \\
\hline Real Estate & 0.16 & 0.18 & 0.18 & 0.16 & 0.12 & 0.12 & 0.12 & 0.08 \\
\hline Other Savings & 0.17 & 0.16 & 0.16 & 0.13 & 0.10 & 0.08 & 0.08 & 0.06 \\
\hline
\end{tabular}

\section{Median Value, Conditional on Holding}

$\begin{array}{lrrrrrrrr}\text { Princ. Resid. } & 127,849 & 122,735 & 121,712 & 117,621 & 104,325 & 102,279 & 86,937 & 81,312 \\ \text { Vehicles } & 12,273 & 10,228 & 10,228 & 10,228 & 9,205 & 6,137 & 5,114 & 4,091 \\ \text { IRAs } & 39,888 & 46,189 & 59,833 & 61,367 & 51,140 & 32,474 & 20,456 & \text { N/A } \\ \text { Stocks } & 40,400 & 46,026 & 51,140 & 61,367 & 51,140 & 76,709 & 51,140 & 84,380 \\ \text { Bonds } & 12,273 & 25,570 & 40,912 & 31,707 & 43,469 & 35,798 & 51,140 & \text { N/A } \\ \text { Bank Accounts } & 5,114 & 5,114 & 7,160 & 8,182 & 8,182 & 9,001 & 7,160 & 6,137 \\ \text { CDs } & 10,228 & 11,251 & 17,387 & 20,456 & 25,570 & 30,684 & 31,707 & 29,661 \\ \text { Business } & 156,556 & 153,419 & 130,406 & 153,419 & 153,419 & 168,760 & \text { N/A } & \text { N/A } \\ \text { Real Estate } & 61,367 & 71,595 & 76,709 & 71,595 & 91,540 & 76,709 & 81,823 & \text { N/A } \\ \text { Other Savings } & 20,456 & 20,456 & 20,456 & 25,570 & 23,524 & 20,456 & 17,899 & \text { N/A } \\ \text { Total Assets } & 185,636 & 169,783 & 175,920 & 184,153 & 174,999 & 142,168 & 122,735 & 92,460\end{array}$

\section{Mean Share of Total Assets}

$\begin{array}{lllllllll}\text { Princ. Resid. } & 0.506 & 0.493 & 0.451 & 0.479 & 0.480 & 0.430 & 0.397 & 0.367 \\ \text { Vehicles } & 0.138 & 0.130 & 0.125 & 0.102 & 0.088 & 0.073 & 0.057 & 0.037 \\ \text { IRAs } & 0.082 & 0.091 & 0.098 & 0.095 & 0.066 & 0.047 & 0.013 & 0.006 \\ \text { Stocks } & 0.064 & 0.064 & 0.064 & 0.067 & 0.083 & 0.094 & 0.091 & 0.119 \\ \text { Bonds } & 0.003 & 0.007 & 0.007 & 0.008 & 0.011 & 0.011 & 0.014 & 0.024 \\ \text { Bank Accounts } & 0.096 & 0.098 & 0.126 & 0.129 & 0.150 & 0.197 & 0.238 & 0.280 \\ \text { CDs } & 0.016 & 0.017 & 0.027 & 0.035 & 0.049 & 0.078 & 0.104 & 0.101 \\ \text { Business } & 0.037 & 0.034 & 0.034 & 0.027 & 0.029 & 0.023 & 0.023 & 0.026 \\ \text { Real Estate } & 0.037 & 0.048 & 0.048 & 0.040 & 0.033 & 0.035 & 0.051 & 0.031 \\ \text { Other Savings } & 0.020 & 0.018 & 0.020 & 0.017 & 0.012 & 0.012 & 0.012 & 0.008 \\ & & & & & & & & \\ \text { \# of HHs } & 1,268 & 2,400 & 2,274 & 1,797 & 1,518 & 1,333 & 700\end{array}$

Notes:

1) Age of household is defined based on the age of the oldest member of the couple.

2) N/A indicates fewer than 50 observations with positive asset value.

3) Values are weighted by HRS household weights. 
Table 2: Effect of Age on Asset Holdings

\begin{tabular}{|c|c|c|c|c|}
\hline Asset Class & Mean & $\begin{array}{c}\text { Linear } \\
\text { Age }\end{array}$ & $\begin{array}{c}\text { with Cohort } \\
\text { Dummies }\end{array}$ & $\begin{array}{c}\text { with Family } \\
\text { Fixed Effects } \\
\end{array}$ \\
\hline$(\mathrm{N}=50,260)$ & \multicolumn{4}{|c|}{ Positive Holdings of Asset Class } \\
\hline Principal Residence & 0.756 & $\begin{array}{l}-0.0048 * * * \\
{[0.0003]}\end{array}$ & $\begin{array}{l}-0.0028 * * * \\
{[0.0010]}\end{array}$ & $\begin{array}{l}-0.0042 * * * \\
{[0.0011]}\end{array}$ \\
\hline Vehicles & 0.791 & $\begin{array}{l}-0.0090 \text { *** } \\
{[0.0002]}\end{array}$ & $\begin{array}{r}-0.0010 \\
{[0.0008]}\end{array}$ & $\begin{array}{l}-0.0039 * * * \\
{[0.0011]}\end{array}$ \\
\hline IRAs/Stocks/Bonds & 0.470 & $\begin{array}{l}-0.0054 * * * \\
{[0.0003]}\end{array}$ & $\begin{array}{l}-0.0049 * * * \\
{[0.0016]}\end{array}$ & $\begin{array}{r}-0.0005 \\
{[0.0012]}\end{array}$ \\
\hline Bank Accounts/CDs & 0.851 & $\begin{array}{r}0.0001 \\
{[0.0002]}\end{array}$ & $\begin{array}{r}-0.0009 \\
{[0.0008]}\end{array}$ & $\begin{array}{r}-0.0010 \\
{[0.0013]}\end{array}$ \\
\hline Business/Real Estate & 0.219 & $\begin{array}{l}-0.0033 \text { *** } \\
{[0.0003]}\end{array}$ & $\begin{array}{r}-0.0005 \\
{[0.0013]}\end{array}$ & $\begin{array}{r}-0.0003 \\
{[0.0012]}\end{array}$ \\
\hline$(\mathrm{N}=47,425)$ & \multicolumn{4}{|c|}{ Share of Holdings in Asset Class } \\
\hline Principal Residence & 0.451 & $\begin{array}{l}-0.0031 * * * \\
{[0.0002]}\end{array}$ & $\begin{array}{l}-0.0031 \text { *** } \\
{[0.00010}\end{array}$ & $\begin{array}{l}-0.0022 * * \\
{[0.0010]}\end{array}$ \\
\hline Vehicles & 0.104 & $\begin{array}{l}-0.0028 * * * \\
{[0.0001]}\end{array}$ & $\begin{array}{r}-0.0003 \\
{[0.0005]}\end{array}$ & $\begin{array}{l}-0.0012 * \\
{[0.0007]}\end{array}$ \\
\hline IRAs/Stocks/Bonds & 0.153 & $\begin{array}{l}-0.0006 * * * \\
{[0.0002]}\end{array}$ & $\begin{array}{l}-0.0012 * \\
{[0.0006]}\end{array}$ & $\begin{array}{r}0.0003 \\
{[0.0007]}\end{array}$ \\
\hline Bank Accounts/CDs & 0.199 & $\begin{array}{l}0.0078 * * * \\
{[0.0001]}\end{array}$ & $\begin{array}{l}0.0040 * * * \\
{[0.0006]}\end{array}$ & $\begin{array}{l}0.0031 * * * \\
{[0.0009]}\end{array}$ \\
\hline Business/Real Estate & 0.076 & $\begin{array}{l}-0.0009 \text { *** } \\
{[0.0001]}\end{array}$ & $\begin{array}{r}0.0007 \\
{[0.0005]}\end{array}$ & $\begin{array}{r}-0.0004 \\
{[0.0006]}\end{array}$ \\
\hline$(\mathrm{N}=50,260)$ & \multicolumn{4}{|c|}{ Dollar Value in Asset Class } \\
\hline Principal Residence & 111,220 & $\begin{array}{l}-1174 * * * \\
{[157]}\end{array}$ & $\begin{array}{r}-809 \\
{[651]}\end{array}$ & $\begin{array}{r}-313 \\
{[644]}\end{array}$ \\
\hline Vehicles & 12,017 & $\begin{array}{l}-350 * * * \\
{[26]}\end{array}$ & $\begin{array}{l}-204 * \\
{[122]}\end{array}$ & $\begin{array}{r}-39 \\
{[78]}\end{array}$ \\
\hline IRAs/Stocks/Bonds & 100,953 & $\begin{array}{r}-44 \\
{[331]}\end{array}$ & $\begin{array}{r}-1434 \\
{[907]}\end{array}$ & $\begin{array}{r}-844 \\
{[1348]}\end{array}$ \\
\hline Bank Accounts/CDs & 42,065 & $\begin{array}{l}1348 * * * \\
{[220]}\end{array}$ & $\begin{array}{l}1530 * \\
{[810]}\end{array}$ & $\begin{array}{r}552 \\
{[978]}\end{array}$ \\
\hline Business/Real Estate & 67,723 & $\begin{array}{l}-1562 * * * \\
{[311]}\end{array}$ & $\begin{array}{r}1337 \\
{[1330]}\end{array}$ & $\begin{array}{r}527 \\
{[1863]}\end{array}$ \\
\hline
\end{tabular}

Note: Coefficient reported is for linear age. Standard errors appear in parentheses. Statistical significance at the $10 \%, 5 \%$, and $1 \%$ levels is indicated by one, two, or three stars, respectively. 
Table 3: Simple Effects of Health Shocks on Asset Holdings

\begin{tabular}{|c|c|c|c|c|c|}
\hline \multirow[t]{2}{*}{ Asset Class } & \multirow[t]{2}{*}{ Mean } & \multirow[t]{2}{*}{ Median } & \multicolumn{3}{|c|}{ Health Shock } \\
\hline & & & Widow & Chronic & Acute \\
\hline $\mathrm{N}=50,304$ & \multicolumn{5}{|c|}{ Positive Holdings of Asset Class } \\
\hline $\begin{array}{l}\text { Principal } \\
\text { Residence }\end{array}$ & 0.756 & & $\begin{array}{l}-0.042 * * * \\
{[0.007]}\end{array}$ & $\begin{array}{r}-0.003 \\
{[0.007]}\end{array}$ & $\begin{array}{r}-0.005 \\
{[0.008]}\end{array}$ \\
\hline Vehicles & 0.791 & & $\begin{array}{l}-0.074 \text { *** } \\
{[0.007]}\end{array}$ & $\begin{array}{l}0.023 \\
{[0.007]}\end{array}$ & $\begin{array}{r}0.012 \\
{[0.008]}\end{array}$ \\
\hline $\begin{array}{l}\text { IRAs/Stocks/ } \\
\text { Bonds }\end{array}$ & 0.469 & & $\begin{array}{r}0.000 \\
{[0.008]}\end{array}$ & $\begin{array}{l}-0.022 * * * \\
{[0.008]}\end{array}$ & $\begin{array}{r}0.001 \\
{[0.009]}\end{array}$ \\
\hline $\begin{array}{l}\text { Bank Accts/ } \\
\text { CDs }\end{array}$ & 0.851 & & $\begin{array}{r}0.008 \\
{[0.008]}\end{array}$ & $\begin{array}{r}0.002 \\
{[0.008]}\end{array}$ & $\begin{array}{r}-0.009 \\
{[0.010]}\end{array}$ \\
\hline $\begin{array}{l}\text { Business/ } \\
\text { Real Estate }\end{array}$ & 0.219 & & $\begin{array}{r}-0.002 \\
{[0.007]}\end{array}$ & $\begin{array}{c}-0.014 * \\
{[0.008]}\end{array}$ & $\begin{array}{l}-0.025 \text { *** } \\
{[0.009]}\end{array}$ \\
\hline $\mathrm{N}=47,467$ & \multicolumn{5}{|c|}{ Share of Holdings in Asset Class } \\
\hline $\begin{array}{l}\text { Principal } \\
\text { Residence }\end{array}$ & 0.451 & 0.436 & $\begin{array}{l}-0.026 \text { *** } \\
{[0.006]}\end{array}$ & $\begin{array}{r}-0.006 \\
{[0.006]}\end{array}$ & $\begin{array}{r}0.004 \\
{[0.007]}\end{array}$ \\
\hline Vehicles & 0.104 & 0.035 & $\begin{array}{l}-0.015 \text { *** } \\
{[0.004]}\end{array}$ & $\begin{array}{r}0.001 \\
{[0.004]}\end{array}$ & $\begin{array}{r}0.003 \\
{[0.005]}\end{array}$ \\
\hline $\begin{array}{l}\text { IRAs/Stocks/ } \\
\text { Bonds }\end{array}$ & 0.153 & 0.000 & $\begin{array}{r}-0.001 \\
{[0.004]}\end{array}$ & $\begin{array}{r}-0.002 \\
{[0.004]}\end{array}$ & $\begin{array}{r}0.003 \\
{[0.005]}\end{array}$ \\
\hline $\begin{array}{l}\text { Bank Accts/ } \\
\text { CDs }\end{array}$ & 0.199 & 0.067 & $\begin{array}{l}0.035 \text { *** } \\
{[0.005]}\end{array}$ & $\begin{array}{r}0.005 \\
{[0.005]}\end{array}$ & $\begin{array}{r}0.004 \\
{[0.006]}\end{array}$ \\
\hline $\begin{array}{l}\text { Business/ } \\
\text { Real Estate }\end{array}$ & 0.076 & 0.000 & $\begin{array}{r}0.005 \\
{[0.004]}\end{array}$ & $\begin{array}{c}-0.002 \\
{[0.004]}\end{array}$ & $\begin{array}{l}-0.014 \text { *** } \\
{[0.004]}\end{array}$ \\
\hline $\mathrm{N}=50,304$ & \multicolumn{5}{|c|}{ Dollar Value in Asset Class } \\
\hline $\begin{array}{l}\text { Principal } \\
\text { Residence }\end{array}$ & 111,246 & 79,018 & $\begin{array}{rl}-8,237 & * * \\
{[3,873]} & \end{array}$ & $\begin{array}{r}56 \\
{[3,946]}\end{array}$ & $\begin{array}{r}190 \\
{[4,692]}\end{array}$ \\
\hline Vehicles & 12,010 & 5,864 & $\begin{array}{r}-1,671 * * * \\
{[559]}\end{array}$ & $\begin{array}{r}497 \\
{[570]}\end{array}$ & $\begin{array}{r}-707 \\
{[678]}\end{array}$ \\
\hline $\begin{array}{l}\text { IRAs/Stocks/ } \\
\text { Bonds }\end{array}$ & 100,870 & 0 & $\begin{array}{l}-22,339 \quad * * * \\
{[8,330]}\end{array}$ & $\begin{array}{r}7,413 \\
{[8,488]}\end{array}$ & $\begin{array}{r}2,706 \\
{[10,093]}\end{array}$ \\
\hline $\begin{array}{l}\text { Bank Accts/ } \\
\text { CDs }\end{array}$ & 42,030 & 7,902 & $\begin{array}{r}-130 \\
{[6,008]}\end{array}$ & $\begin{array}{r}5,037 \\
{[6,122]}\end{array}$ & $\begin{array}{r}4,369 \\
{[7,280]}\end{array}$ \\
\hline $\begin{array}{l}\text { Business/ } \\
\text { Real Estate }\end{array}$ & 67,777 & 0 & $\begin{array}{r}2,379 \\
{[11,516]}\end{array}$ & $\begin{array}{r}-908 \\
{[11,735]}\end{array}$ & $\begin{array}{r}-4486 \\
{[13,954]}\end{array}$ \\
\hline Total Assets & 342,208 & 151,782 & $\begin{array}{c}-30,655 * \\
{[18,122]}\end{array}$ & $\begin{array}{r}14,725 \\
{[18,466]}\end{array}$ & $\begin{array}{r}2,728 \\
{[21,958]}\end{array}$ \\
\hline
\end{tabular}

Coefficient reported is for a dummy variable indicating the given health shock was suffered in a previous period. Standard errors appear in parentheses. Statistical significance at the $10 \%, 5 \%$, and $1 \%$ levels is indicated with two, or three stars, respectively. 
Table 4: Dynamic Effects of Health Shocks on Positive Holdings of Asset Class

\begin{tabular}{|c|c|c|c|c|c|c|}
\hline \multirow[t]{2}{*}{ Asset Class } & \multirow[t]{2}{*}{ Mean } & \multicolumn{5}{|c|}{ Distance From Shock } \\
\hline & & 3 Before & 2 Before & 1 After & 2 After & 3 After \\
\hline$(\mathrm{N}=9,049)$ & & & Wis & shock & & \\
\hline $\begin{array}{l}\text { Principal } \\
\text { Residence }\end{array}$ & 0.758 & $\begin{array}{r}-0.016 \\
{[0.013]}\end{array}$ & $\begin{array}{r}-0.001 \\
{[0.010]}\end{array}$ & $\begin{array}{l}-0.046 * * * \\
{[0.009]}\end{array}$ & $\begin{array}{l}-0.057 * * * \\
{[0.012]}\end{array}$ & $\begin{array}{l}-0.049 * * * \\
{[0.016]}\end{array}$ \\
\hline Vehicles & 0.801 & $\begin{array}{l}0.035 * * * \\
{[0.013]}\end{array}$ & $\begin{array}{c}0.017 \\
{[0.010]}\end{array}$ & $\begin{array}{l}-0.086 * * * \\
{[0.009]}\end{array}$ & $\begin{array}{l}-0.104 * * * \\
{[0.012]}\end{array}$ & $\begin{array}{l}-0.127 \text { *** } \\
{[0.016]}\end{array}$ \\
\hline $\begin{array}{l}\text { IRAs/Stocks } \\
\text { Bonds }\end{array}$ & 0.429 & $\begin{array}{r}0.002 \\
{[0.014]}\end{array}$ & $\begin{array}{l}0.026 \text { ** } \\
{[0.010]}\end{array}$ & $\begin{array}{r}0.005 \\
{[0.010]}\end{array}$ & $\begin{array}{r}-0.018 \\
{[0.013]}\end{array}$ & $\begin{array}{r}-0.005 \\
{[0.017]}\end{array}$ \\
\hline $\begin{array}{l}\text { Bank Accts/ } \\
\text { CDs }\end{array}$ & 0.845 & $\begin{array}{r}-0.018 \\
{[0.014]}\end{array}$ & $\begin{array}{r}0.004 \\
{[0.011]}\end{array}$ & $\begin{array}{l}0.025 \text { ** } \\
{[0.010]}\end{array}$ & $\begin{array}{l}0.043 \text { *** } \\
{[0.013]}\end{array}$ & $\begin{array}{l}0.049 \text { *** } \\
{[0.017]}\end{array}$ \\
\hline $\begin{array}{l}\text { Business/ } \\
\text { Real Estate }\end{array}$ & 0.187 & $\begin{array}{l}0.060 * * * \\
{[0.013]}\end{array}$ & $\begin{array}{l}0.034 \text { *** } \\
{[0.010]}\end{array}$ & $\begin{array}{r}-0.005 \\
{[0.009]}\end{array}$ & $\begin{array}{l}-0.043 * * * \\
{[0.012]}\end{array}$ & $\begin{array}{l}-0.069 \text { *** } \\
{[0.016]}\end{array}$ \\
\hline$(\mathrm{N}=8,346)$ & & & Chr & shock & & \\
\hline $\begin{array}{l}\text { Principal } \\
\text { Residence }\end{array}$ & 0.881 & $\begin{array}{l}-0.037 \text { *** } \\
{[0.013]}\end{array}$ & $\begin{array}{r}-0.004 \\
{[0.010]}\end{array}$ & $\begin{array}{r}-0.006 \\
{[0.009]}\end{array}$ & $\begin{array}{r}-0.015 \\
{[0.011]}\end{array}$ & $\begin{array}{l}-0.040 \text { *** } \\
{[0.014]}\end{array}$ \\
\hline Vehicles & 0.930 & $\begin{array}{r}-0.005 \\
{[0.012]}\end{array}$ & $\begin{array}{r}-0.009 \\
{[0.009]}\end{array}$ & $\begin{array}{r}-0.003 \\
{[0.009]}\end{array}$ & $\begin{array}{l}-0.029 * * * \\
{[0.011]}\end{array}$ & $\begin{array}{l}-0.060 * * * \\
{[0.013]}\end{array}$ \\
\hline $\begin{array}{l}\text { IRAs/Stocks } \\
\text { Bonds }\end{array}$ & 0.584 & $\begin{array}{c}0.029 * \\
{[0.017]}\end{array}$ & $\begin{array}{r}0.010 \\
{[0.013]}\end{array}$ & $\begin{array}{c}-0.021 * \\
{[0.012]}\end{array}$ & $\begin{array}{c}-0.028 * \\
{[0.015]}\end{array}$ & $\begin{array}{l}-0.053 * * * \\
{[0.019]}\end{array}$ \\
\hline $\begin{array}{l}\text { Bank Accts/ } \\
\text { CDs }\end{array}$ & 0.901 & $\begin{array}{r}0.017 \\
{[0.016]}\end{array}$ & $\begin{array}{r}0.004 \\
{[0.012]}\end{array}$ & $\begin{array}{r}0.012 \\
{[0.011]}\end{array}$ & $\begin{array}{r}0.010 \\
{[0.014]}\end{array}$ & $\begin{array}{r}0.004 \\
{[0.017]}\end{array}$ \\
\hline $\begin{array}{l}\text { Business/ } \\
\text { Real Estate }\end{array}$ & 0.287 & $\begin{array}{l}0.071 * * * \\
{[0.018]}\end{array}$ & $\begin{array}{r}0.017 \\
{[0.013]}\end{array}$ & $\begin{array}{l}-0.024 * * \\
{[0.012]}\end{array}$ & $\begin{array}{l}-0.039 * * \\
{[0.015]}\end{array}$ & $\begin{array}{l}-0.071 * * * \\
{[0.019]}\end{array}$ \\
\hline$(\mathrm{N}=5,323)$ & & & & hock & & \\
\hline $\begin{array}{l}\text { Principal } \\
\text { Residence }\end{array}$ & 0.877 & $\begin{array}{r}-0.006 \\
{[0.016]}\end{array}$ & $\begin{array}{r}0.002 \\
{[0.011]}\end{array}$ & $\begin{array}{r}-0.010 \\
{[0.011]}\end{array}$ & $\begin{array}{r}-0.022 \\
{[0.014]}\end{array}$ & $\begin{array}{l}-0.057 \text { *** } \\
{[0.018]}\end{array}$ \\
\hline Vehicles & 0.933 & $\begin{array}{r}-0.008 \\
{[0.015]}\end{array}$ & $\begin{array}{r}-0.002 \\
{[0.011]}\end{array}$ & $\begin{array}{l}-0.025 * * \\
{[0.010]}\end{array}$ & $\begin{array}{l}-0.047 * * * \\
{[0.013]}\end{array}$ & $\begin{array}{l}-0.074 * * * \\
{[0.016]}\end{array}$ \\
\hline $\begin{array}{l}\text { IRAs/Stocks } \\
\text { Bonds }\end{array}$ & 0.583 & $\begin{array}{r}-0.001 \\
{[0.019]}\end{array}$ & $\begin{array}{r}0.013 \\
{[0.014]}\end{array}$ & $\begin{array}{r}-0.020 \\
{[0.014]}\end{array}$ & $\begin{array}{r}-0.005 \\
{[0.017]}\end{array}$ & $\begin{array}{r}-0.020 \\
{[0.022]}\end{array}$ \\
\hline $\begin{array}{l}\text { Bank Accts/ } \\
\text { CDs }\end{array}$ & 0.899 & $\begin{array}{r}0.001 \\
{[0.018]}\end{array}$ & $\begin{array}{r}0.007 \\
{[0.013]}\end{array}$ & $\begin{array}{r}-0.005 \\
{[0.013]}\end{array}$ & $\begin{array}{r}0.005 \\
{[0.016]}\end{array}$ & $\begin{array}{r}-0.007 \\
{[0.021]}\end{array}$ \\
\hline $\begin{array}{l}\text { Business/ } \\
\text { Real Estate }\end{array}$ & 0.283 & $\begin{array}{r}0.016 \\
{[0.021]}\end{array}$ & $\begin{array}{r}0.020 \\
{[0.015]}\end{array}$ & $\begin{array}{l}-0.038 * * * \\
{[0.015]}\end{array}$ & $\begin{array}{l}-0.087 * * * \\
{[0.019]}\end{array}$ & $\begin{array}{l}-0.126 \text { *** } \\
{[0.024]}\end{array}$ \\
\hline
\end{tabular}

Coefficient reported is for a dummy variable " $\mathrm{X}$ " periods away from the health shock. The excluded dummy is for the period before the shock. Standard errors appear in parentheses. Statistical significance at the $10 \%, 5 \%$, and $1 \%$ levels is indicated with two, or three stars, respectively. 
Table 5: Dynamic Effects of Health Shocks on Asset Shares

\begin{tabular}{|c|c|c|c|c|c|c|}
\hline \multirow[t]{2}{*}{ Asset Class } & \multirow[t]{2}{*}{ Mean } & \multicolumn{5}{|c|}{ Distance From Shock } \\
\hline & & 3 Before & 2 Before & 1 After & 2 After & 3 After \\
\hline$(\mathrm{N}=8,588)$ & \multicolumn{6}{|c|}{ Widow shock } \\
\hline $\begin{array}{l}\text { Principal } \\
\text { Residence }\end{array}$ & 0.465 & $\begin{array}{l}-0.021 * \\
{[0.012]}\end{array}$ & $\begin{array}{r}-0.012 \\
{[0.009]}\end{array}$ & $\begin{array}{l}-0.030 * * * \\
{[0.008]}\end{array}$ & $\begin{array}{l}-0.027 * * \\
{[0.011]}\end{array}$ & $\begin{array}{r}-0.018 \\
{[0.014]}\end{array}$ \\
\hline Vehicles & 0.109 & $\begin{array}{l}0.017 \text { ** } \\
{[0.008]}\end{array}$ & $\begin{array}{r}0.000 \\
{[0.006]}\end{array}$ & $\begin{array}{l}-0.017 \text { *** } \\
{[0.006]}\end{array}$ & $\begin{array}{l}-0.020 * * * \\
{[0.007]}\end{array}$ & $\begin{array}{l}-0.023 \text { ** } \\
{[0.009]}\end{array}$ \\
\hline $\begin{array}{l}\text { IRAs/Stocks } \\
\text { Bonds }\end{array}$ & 0.134 & $\begin{array}{r}-0.004 \\
{[0.007]}\end{array}$ & $\begin{array}{r}0.006 \\
{[0.005]}\end{array}$ & $\begin{array}{r}0.006 \\
{[0.005]}\end{array}$ & $\begin{array}{c}0.012 * \\
{[0.007]}\end{array}$ & $\begin{array}{l}0.022 \\
{[0.009]}\end{array}$ \\
\hline $\begin{array}{l}\text { Bank Accts/ } \\
\text { CDs }\end{array}$ & 0.212 & $\begin{array}{r}-0.004 \\
{[0.010]}\end{array}$ & $\begin{array}{r}-0.004 \\
{[0.008]}\end{array}$ & $\begin{array}{l}0.037 \text { *** } \\
{[0.007]}\end{array}$ & $\begin{array}{l}0.042 \text { *** } \\
{[0.009]}\end{array}$ & $\begin{array}{l}0.033 \text { *** } \\
{[0.012]}\end{array}$ \\
\hline $\begin{array}{l}\text { Business/ } \\
\text { Real Estate }\end{array}$ & 0.063 & $\begin{array}{r}0.008 \\
{[0.006]}\end{array}$ & $\begin{array}{l}0.01 * * \\
{[0.005]}\end{array}$ & $\begin{array}{r}0.003 \\
{[0.005]}\end{array}$ & $\begin{array}{r}-0.007 \\
{[0.006]}\end{array}$ & $\begin{array}{c}-0.014 * \\
{[0.008]}\end{array}$ \\
\hline$(\mathrm{N}=8,224)$ & \multicolumn{6}{|c|}{ Chronic shock } \\
\hline $\begin{array}{l}\text { Principal } \\
\text { Residence }\end{array}$ & 0.463 & $\begin{array}{l}-0.025 \text { ** } \\
{[0.012]}\end{array}$ & $\begin{array}{r}0.002 \\
{[0.009]}\end{array}$ & $\begin{array}{r}0.004 \\
{[0.009]}\end{array}$ & $\begin{array}{r}0.002 \\
{[0.011]}\end{array}$ & $\begin{array}{r}0.001 \\
{[0.014]}\end{array}$ \\
\hline Vehicles & 0.100 & $\begin{array}{r}0.010 \\
{[0.008]}\end{array}$ & $\begin{array}{r}0.001 \\
{[0.006]}\end{array}$ & $\begin{array}{r}-0.004 \\
{[0.006]}\end{array}$ & $\begin{array}{l}-0.016 * * \\
{[0.007]}\end{array}$ & $\begin{array}{l}-0.021 * * \\
{[0.009]}\end{array}$ \\
\hline $\begin{array}{l}\text { IRAs/Stocks } \\
\text { Bonds }\end{array}$ & 0.179 & $\begin{array}{l}-0.022 * * \\
{[0.009]}\end{array}$ & $\begin{array}{r}-0.010 \\
{[0.007]}\end{array}$ & $\begin{array}{r}0.004 \\
{[0.006]}\end{array}$ & $\begin{array}{r}0.008 \\
{[0.008]}\end{array}$ & $\begin{array}{r}0.011 \\
{[0.010]}\end{array}$ \\
\hline $\begin{array}{l}\text { Bank Accts/ } \\
\text { CDs }\end{array}$ & 0.149 & $\begin{array}{r}0.004 \\
{[0.010]}\end{array}$ & $\begin{array}{r}-0.003 \\
{[0.007]}\end{array}$ & $\begin{array}{r}0.007 \\
{[0.007]}\end{array}$ & $\begin{array}{l}0.022 \text { *** } \\
{[0.008]}\end{array}$ & $\begin{array}{l}0.035 \text { *** } \\
{[0.011]}\end{array}$ \\
\hline $\begin{array}{l}\text { Business/ } \\
\text { Real Estate }\end{array}$ & 0.092 & $\begin{array}{l}0.023 * * * \\
{[0.007]}\end{array}$ & $\begin{array}{r}0.007 \\
{[0.006]}\end{array}$ & $\begin{array}{l}-0.012 * * \\
{[0.005]}\end{array}$ & $\begin{array}{l}-0.018 * * * \\
{[0.006]}\end{array}$ & $\begin{array}{l}-0.024 * * * \\
{[0.008]}\end{array}$ \\
\hline$(\mathrm{N}=5,254)$ & \multicolumn{6}{|c|}{ Acute shock } \\
\hline $\begin{array}{l}\text { Principal } \\
\text { Residence }\end{array}$ & 0.464 & $\begin{array}{r}0.004 \\
{[0.014]}\end{array}$ & $\begin{array}{c}-0.018 * \\
{[0.011]}\end{array}$ & $\begin{array}{r}-0.004 \\
{[0.010]}\end{array}$ & $\begin{array}{r}-0.005 \\
{[0.013]}\end{array}$ & $\begin{array}{r}-0.005 \\
{[0.016]}\end{array}$ \\
\hline Vehicles & 0.095 & $\begin{array}{r}-0.001 \\
{[0.008]}\end{array}$ & $\begin{array}{r}0.004 \\
{[0.006]}\end{array}$ & $\begin{array}{r}-0.005 \\
{[0.006]}\end{array}$ & $\begin{array}{l}-0.015 * \\
{[0.008]}\end{array}$ & $\begin{array}{r}-0.001 \\
{[0.010]}\end{array}$ \\
\hline $\begin{array}{l}\text { IRAs/Stocks } \\
\text { Bonds }\end{array}$ & 0.177 & $\begin{array}{r}-0.006 \\
{[0.010]}\end{array}$ & $\begin{array}{r}0.005 \\
{[0.008]}\end{array}$ & $\begin{array}{r}0.006 \\
{[0.007]}\end{array}$ & $\begin{array}{r}0.01 \\
{[0.009]}\end{array}$ & $\begin{array}{r}0.018 \\
{[0.012]}\end{array}$ \\
\hline $\begin{array}{l}\text { Bank Accts/ } \\
\text { CDs }\end{array}$ & 0.157 & $\begin{array}{r}-0.006 \\
{[0.011]}\end{array}$ & $\begin{array}{r}-0.009 \\
{[0.008]}\end{array}$ & $\begin{array}{r}0.012 \\
{[0.008]}\end{array}$ & $\begin{array}{l}0.022 \\
{[0.010]}\end{array}$ & $\begin{array}{l}0.027 * * \\
{[0.013]}\end{array}$ \\
\hline $\begin{array}{l}\text { Business/ } \\
\text { Real Estate }\end{array}$ & 0.089 & $\begin{array}{r}0.011 \\
{[0.009]}\end{array}$ & $\begin{array}{c}0.013 * \\
{[0.007]}\end{array}$ & $\begin{array}{c}-0.011 * \\
{[0.006]}\end{array}$ & $\begin{array}{l}-0.018 * * \\
{[0.008]}\end{array}$ & $\begin{array}{l}-0.037 * * * \\
{[0.010]}\end{array}$ \\
\hline
\end{tabular}

Coefficient reported is for a dummy variable " $\mathrm{X}$ " periods away from the health shock. The excluded dummy is for the period before the shock. Standard errors appear in parentheses. Statistical significance at the $10 \%, 5 \%$, and $1 \%$ levels is indicated with two, or three stars, respectively. 
Table 6: Reasons Why Widow Shock Affects Asset Holdings

\begin{tabular}{|c|c|c|c|c|c|c|}
\hline & Main effect & 3 Before & 2 Before & 1 After & 2 After & 3 After \\
\hline \multicolumn{7}{|c|}{ Principal Residence Ownership } \\
\hline Base & & $\begin{array}{r}-0.011 \\
{[0.017]}\end{array}$ & $\begin{array}{r}-0.005 \\
{[0.013]}\end{array}$ & $\begin{array}{l}-0.035 * * * \\
{[0.012]}\end{array}$ & $\begin{array}{l}-0.043 * * * \\
{[0.015]}\end{array}$ & $\begin{array}{c}-0.038 * \\
{[0.021]}\end{array}$ \\
\hline ADL1 & $\begin{array}{l}-0.061 * * \\
{[0.027]}\end{array}$ & $\begin{array}{r}0.020 \\
{[0.029]}\end{array}$ & $\begin{array}{r}-0.008 \\
{[0.024]}\end{array}$ & $\begin{array}{r}-0.032 \\
{[0.022]}\end{array}$ & $\begin{array}{l}-0.065 * * \\
{[0.027]}\end{array}$ & $\begin{array}{l}-0.098 * * * \\
{[0.036]}\end{array}$ \\
\hline Manage Money & $\begin{array}{r}-0.042 \\
{[0.036]}\end{array}$ & $\begin{array}{r}0.033 \\
{[0.040]}\end{array}$ & $\begin{array}{c}0.081 \\
{[0.033]}\end{array}$ & $\begin{array}{l}-0.100 * * * \\
{[0.029]}\end{array}$ & $\begin{array}{l}-0.099 * * \\
{[0.040]}\end{array}$ & $\begin{array}{l}-0.120 * * \\
{[0.058]}\end{array}$ \\
\hline OOP5 & $\begin{array}{r}0.018 \\
{[0.029]}\end{array}$ & $\begin{array}{r}-0.020 \\
{[0.030]}\end{array}$ & $\begin{array}{r}-0.009 \\
{[0.024]}\end{array}$ & $\begin{array}{r}0.038 \\
{[0.025]}\end{array}$ & $\begin{array}{r}-0.003 \\
{[0.027]}\end{array}$ & $\begin{array}{r}-0.013 \\
{[0.034]}\end{array}$ \\
\hline \multicolumn{7}{|c|}{ Vehicle Ownership } \\
\hline Base & & $\begin{array}{c}0.032 * \\
{[0.017]}\end{array}$ & $\begin{array}{r}0.007 \\
{[0.013]}\end{array}$ & $\begin{array}{l}-0.064 * * * \\
{[0.012]}\end{array}$ & $\begin{array}{l}-0.092 * * * \\
{[0.015]}\end{array}$ & $\begin{array}{l}-0.129 * * * \\
{[0.020]}\end{array}$ \\
\hline ADL1 & $\begin{array}{r}0.008 \\
{[0.018]}\end{array}$ & $\begin{array}{l}0.066 * * \\
{[0.029]}\end{array}$ & $\begin{array}{r}0.043 * \\
{[0.024]}\end{array}$ & $\begin{array}{l}-0.076 * * * \\
{[0.021]}\end{array}$ & $\begin{array}{l}-0.089 * * * \\
{[0.027]}\end{array}$ & $\begin{array}{l}-0.099 * * * \\
{[0.036]}\end{array}$ \\
\hline Manage Money & $\begin{array}{r}0.014 \\
{[0.023]}\end{array}$ & $\begin{array}{r}0.051 \\
{[0.040]}\end{array}$ & $\begin{array}{r}0.025 \\
{[0.033]}\end{array}$ & $\begin{array}{l}-0.144 \text { *** } \\
{[0.029]}\end{array}$ & $\begin{array}{l}-0.186 \text { *** } \\
{[0.039]}\end{array}$ & $\begin{array}{l}-0.220 * * * \\
{[0.058]}\end{array}$ \\
\hline OOP5 & $\begin{array}{r}-0.023 \\
{[0.017]}\end{array}$ & $\begin{array}{r}-0.010 \\
{[0.030]}\end{array}$ & $\begin{array}{r}0.022 \\
{[0.024]}\end{array}$ & $\begin{array}{c}0.045^{*} \\
{[0.024]}\end{array}$ & $\begin{array}{r}-0.011 \\
{[0.027]}\end{array}$ & $\begin{array}{r}-0.015 \\
{[0.033]}\end{array}$ \\
\hline \multicolumn{7}{|c|}{ Business / Real Estate Ownership } \\
\hline Base & & $\begin{array}{l}0.048 \text { *** } \\
{[0.018]}\end{array}$ & $\begin{array}{c}0.033 \text { ** } \\
{[0.014]}\end{array}$ & $\begin{array}{r}-0.007 \\
{[0.012]}\end{array}$ & $\begin{array}{l}-0.048 \text { *** } \\
{[0.016]}\end{array}$ & $\begin{array}{l}-0.072 \text { *** } \\
{[0.021]}\end{array}$ \\
\hline ADL1 & $\begin{array}{r}0.008 \\
{[0.018]}\end{array}$ & $\begin{array}{r}0.037 \\
{[0.030]}\end{array}$ & $\begin{array}{r}0.001 \\
{[0.025]}\end{array}$ & $\begin{array}{r}0.019 \\
{[0.022]}\end{array}$ & $\begin{array}{r}0.031 \\
{[0.028]}\end{array}$ & $\begin{array}{r}0.024 \\
{[0.037]}\end{array}$ \\
\hline Manage Money & $\begin{array}{r}0.014 \\
{[0.023]}\end{array}$ & $\begin{array}{r}-0.031 \\
{[0.041]}\end{array}$ & $\begin{array}{r}0.018 \\
{[0.034]}\end{array}$ & $\begin{array}{r}0.012 \\
{[0.030]}\end{array}$ & $\begin{array}{r}0.020 \\
{[0.041]}\end{array}$ & $\begin{array}{r}-0.004 \\
{[0.060]}\end{array}$ \\
\hline OOP5 & $\begin{array}{r}-0.023 \\
{[0.017]}\end{array}$ & $\begin{array}{r}0.036 \\
{[0.031]}\end{array}$ & $\begin{array}{r}-0.005 \\
{[0.024]}\end{array}$ & $\begin{array}{r}-0.027 \\
{[0.025]}\end{array}$ & $\begin{array}{r}0.002 \\
{[0.028]}\end{array}$ & $\begin{array}{r}-0.031 \\
{[0.035]}\end{array}$ \\
\hline \multicolumn{7}{|c|}{ Bank accounts / CDs share } \\
\hline Base & & $\begin{array}{r}0.001 \\
{[0.014]}\end{array}$ & $\begin{array}{r}-0.002 \\
{[0.010]}\end{array}$ & $\begin{array}{l}0.026 \text { *** } \\
{[0.009]}\end{array}$ & $\begin{array}{l}0.034 \text { *** } \\
{[0.012]}\end{array}$ & $\begin{array}{r}0.009 \\
{[0.016]}\end{array}$ \\
\hline ADL1 & $\begin{array}{r}0.008 \\
{[0.018]}\end{array}$ & $\begin{array}{r}-0.025 \\
{[0.023]}\end{array}$ & $\begin{array}{r}-0.005 \\
{[0.019]}\end{array}$ & $\begin{array}{r}0.018 \\
{[0.017]}\end{array}$ & $\begin{array}{r}0.028 \\
{[0.022]}\end{array}$ & $\begin{array}{l}0.091 * * * \\
{[0.030]}\end{array}$ \\
\hline Manage Money & $\begin{array}{r}0.014 \\
{[0.023]}\end{array}$ & $\begin{array}{r}-0.010 \\
{[0.033]}\end{array}$ & $\begin{array}{r}0.006 \\
{[0.026]}\end{array}$ & $\begin{array}{l}0.081 \text { *** } \\
{[0.024]}\end{array}$ & $\begin{array}{l}0.082 \text { ** } \\
{[0.033]}\end{array}$ & $\begin{array}{l}0.199 * * * \\
{[0.049]}\end{array}$ \\
\hline OOP5 & $\begin{array}{r}-0.023 \\
{[0.017]} \\
\end{array}$ & $\begin{array}{r}0.000 \\
{[0.024]} \\
\end{array}$ & $\begin{array}{r}0.004 \\
{[0.019]} \\
\end{array}$ & $\begin{array}{r}-0.003 \\
{[0.019]} \\
\end{array}$ & $\begin{array}{r}0.015 \\
{[0.022]} \\
\end{array}$ & $\begin{array}{r}0.032 \\
{[0.026]} \\
\end{array}$ \\
\hline
\end{tabular}

Coefficient reported is for a dummy variable " $\mathrm{X}$ " periods away from the health shock. The excluded dummy is for the period before the shock. Standard errors appear in parentheses. Statistical significance at the $10 \%, 5 \%$, and $1 \%$ levels is indicated with two, or three stars, respectively. 